\title{
Efficiency Analysis of Energy Networks : An International Survey of Regulators
}

Aoife Brophy Haney and Michael Pollitt

June 2009

CWPE 0926 \& EPRG 0915 


\title{
圈圈 UNIVERSITY OF CAMBRIDGE \\ Electricity Policy \\ Research Group
}

\section{Efficiency Analysis of Energy Networks: An International Survey of Regulators}

\author{
EPRG Working Paper 0915
}

Cambridge Working Paper in Economics 0926

\section{Aoife Brophy Haney \& Michael G. Pollitt}

\begin{abstract}
Incentive regulation for networks has been an important part of the reform agenda in a number of countries. As part of this regulatory process, incentives are put in place to improve the cost efficiency of network companies by rewarding good performance relative to a predefined benchmark. The techniques used to establish benchmarks are central to the efficiency improvements that are ultimately achieved. Much experience has been gained internationally in the application of benchmarking techniques and we now have a solid understanding of the main indicators of best practice. These include the use of frontier-based methods; a large and high quality dataset; panel data; and bootstrapping techniques. What we are lacking is a more complete understanding of the factors that influence choice of methods by regulators, i.e. characteristics that may encourage or discourage regulators to adopt best practice methods.
\end{abstract}

In this paper, we present the results of an international survey of energy regulators in 40 countries conducted electronically between June and October 2008. Regulators from European, Australasian and Latin American countries are represented in the survey. The survey questions fall into two main categories. The first set of questions relates to the specific benchmarking techniques used for electricity and gas transmission and distribution; and the second set involves a closer look at the benchmarking analysis process. As an extension of the survey, we compile a best practice index and compute scores for each of the countries 


\section{疄圈 UNIVERSITY OF \\ CAMBRIDGE \\ Electricity Policy \\ Research Group}

involved. Our results show that benchmarking techniques are now widespread in the regulation of gas and electricity networks. Best practice, however, is limited to a small number of regulators. We conclude by summarising existing trends and offering some recommendations on overcoming barriers to best practice efficiency analysis.

Keywords

Electricity; Gas; Benchmarking; Efficiency analysis; Incentive regulation; Energy networks

Contact

Publication

Financial Support aoife.brophy@econ.cam.ac.uk June 2009

ESRC, Electricity Policy Research Group 


\title{
Efficiency Analysis of Energy Networks:
}

\section{An International Survey of Regulators ${ }^{1}$}

\author{
Aoife Brophy Haney ${ }^{2}$ \\ ESRC Electricity Policy Research Group and \\ Faculty of Economics, University of Cambridge
}

Michael G. Pollitt

ESRC Electricity Policy Research Group and

Judge Business School, University of Cambridge

\section{October 09}

This paper is a work in progress and presents preliminary research findings. You are advised to cite with caution unless you first contact the author regarding possible amendments.

\footnotetext{
${ }^{1}$ The authors wish to thank all the regulatory staff who responded to the survey; without them this work would not have been possible. The authors gratefully acknowledge the financial support of the ESRC Electricity Policy Research Group; the assistance of Karim Anaya and William Yu; and the comments of two anonymous referees and participants at the EWEPA 2009 meeting in Pisa. Michael Pollitt wishes to thank Melvyn Weeks and the 2008 NAPW conference for their encouragement in undertaking this survey.

${ }^{2}$ Corresponding author: Faculty of Economics, University of Cambridge, Austin Robinson Building, Sidgwick Avenue, Cambridge CB3 9DE, United Kingdom. t: +44 (0)1223 335285, e: ab748@cam.ac.uk
} 


\title{
Efficiency Analysis of Energy Networks: An International Survey of Regulators
}

\begin{abstract}
Incentive regulation for networks has been an important part of the reform agenda in a number of countries. As part of this regulatory process, incentives are put in place to improve the cost efficiency of network companies by rewarding good performance relative to a pre-defined benchmark. The techniques used to establish benchmarks are central to the efficiency improvements that are ultimately achieved. Much experience has been gained internationally in the application of benchmarking techniques and we now have a solid understanding of the main indicators of best practice. What we are lacking is a more complete understanding of the factors that influence choice of methods by regulators. In this paper, we present the results of an international survey of energy regulators in 40 countries conducted electronically between June and October 2008. Regulators from European, Australasian and Latin American countries are represented in the survey. Our results show that benchmarking techniques are now widespread in the regulation of gas and electricity networks. Best practice, however, is limited to a small number of regulators. We conclude by summarising existing trends and offering some recommendations on overcoming barriers to best practice efficiency analysis.
\end{abstract}

Key words: Benchmarking; Incentive regulation; Energy networks 


\section{Contents}

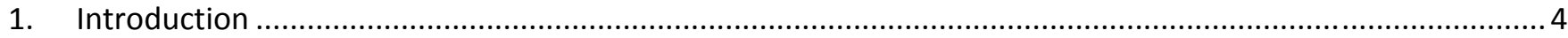

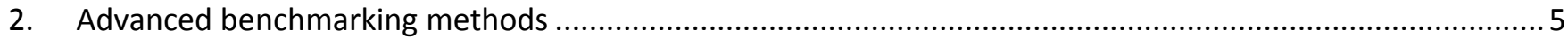

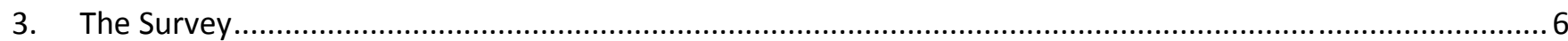

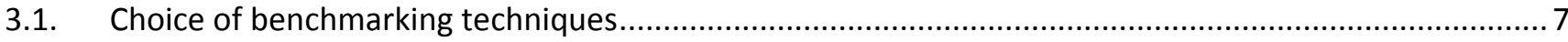

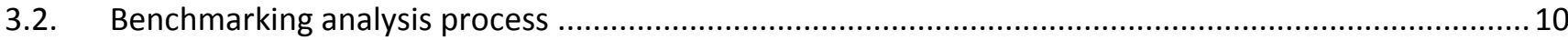

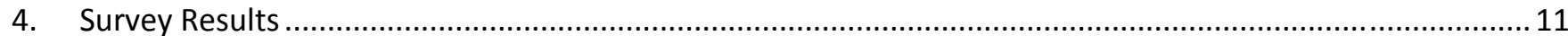

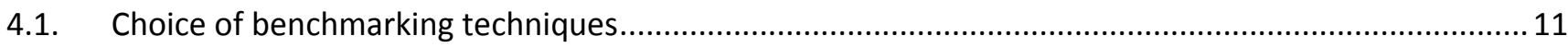

4.1.1. Who uses benchmarking techniques? ................................................................................ 15

4.1.2. Which benchmarking techniques are used? ................................................................... 17

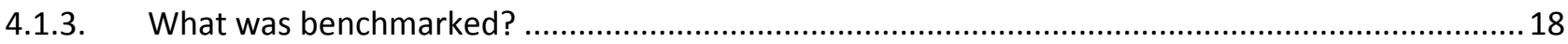

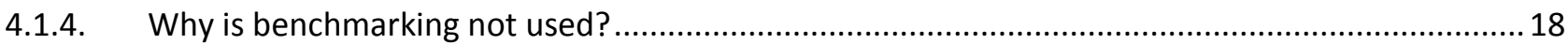

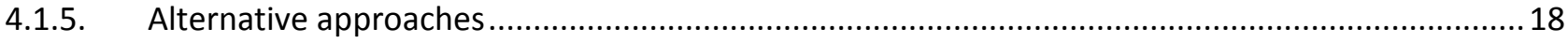

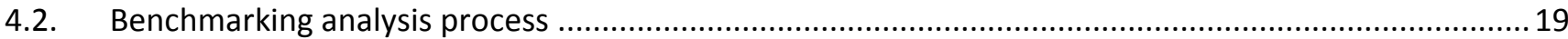

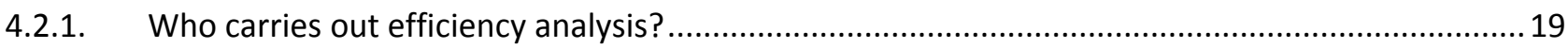

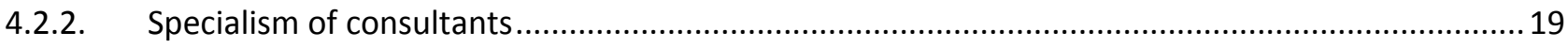

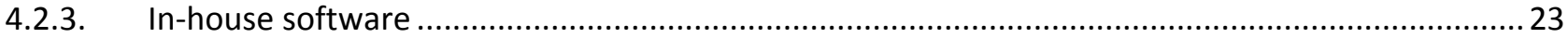

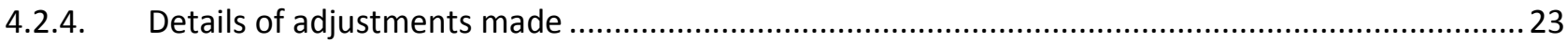

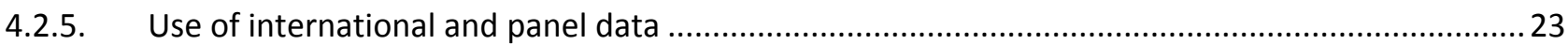

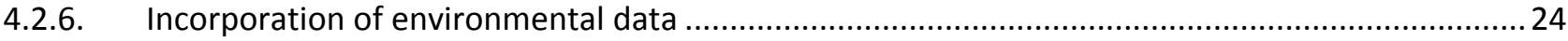

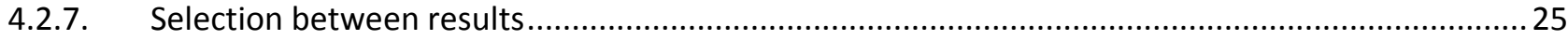

4.2.8. Practicality and desirability of applying latest advances .......................................................2 27

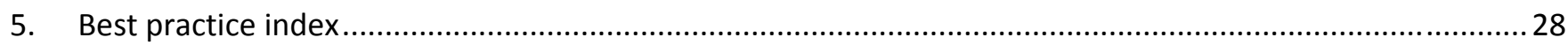

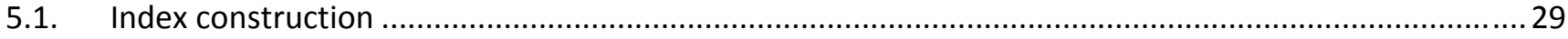

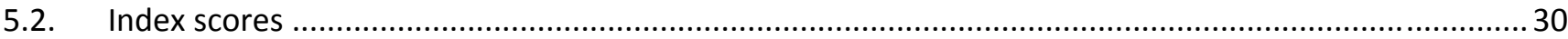

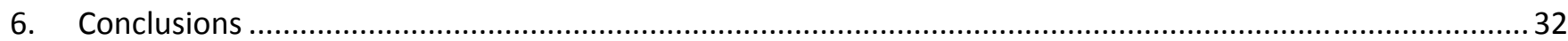

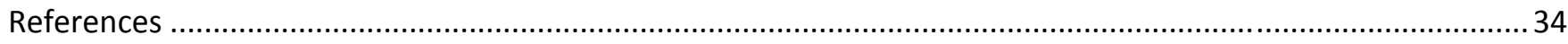

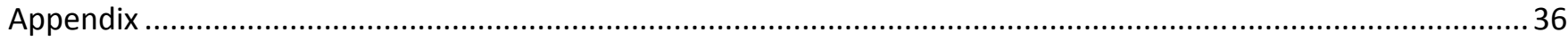




\section{Introduction}

Reform of network industries around the world has typically involved the separation of potentially competitive activities from natural monopoly activities. In the electricity and gas industries, transmission and distribution networks continue to be regulated due to their natural monopoly characteristics. An important part of the reform agenda in a number of countries has been the development of incentive regulation for networks. The overall aim of an incentive-based regime is to imitate competitive market pressures in order to increase efficiency and ultimately pass these efficiency gains on to consumers (Joskow, 2006).

The price review process is the centrepiece of network regulation. As part of this process, the revenue requirements of regulated companies are assessed and plans for future investment are audited. The assessment typically involves benchmarking existing capital and operating costs and setting efficiency improvement factors for each firm. The overall aim is to put in place strong incentives for cost efficiency by rewarding good performance relative to a pre-defined benchmark for a fixed period, usually of 3 to 5 years (Jamasb and Pollitt, 2001; Pollitt, 2008). The outcome of a price review often involves the setting of a price path for the regulated services using a CPI-X (or RPI-X) formula (following Littlechild, 1983).

Differences across countries in approaches to network regulation have previously been analysed in significant detail for the electricity industry (Jamasb and Pollitt, 2001). Jamasb and Pollitt look in particular at the extent to which benchmarking techniques are used and the features of these techniques, mainly in OECD countries. Ten of the 22 countries surveyed in 2000 used some form of benchmarking; half of these used frontier-based methods; and other countries were considering adopting benchmarking measures at the time of the survey.

More recently, the same authors have drawn lessons from the British experience with incentive regulation of electricity distribution for other countries (Jamasb and Pollitt, 2007). Some of the insights of this work include the importance of supplementing a cost-oriented approach with other measures of performance, for example quality of service targets; the crucial role of high-quality data and standardisation of reporting; and the desirability for regulators to use a large number of utilities for comparison and efficiency benchmarking. In other industries, for example the water industry, crosscountry comparisons have shown that incentive regulation has a significant positive effect on efficiency (De Witte and Marques, 2007).

In this paper, we present results from a new survey conducted among energy regulatory agencies in 40 countries. Regulators from European, Australasian and Latin American countries are represented in the survey. The focus of the questions is not only on identifying the use and choice of benchmarking techniques, but also on the main reasons why regulators have chosen to do what they do. Regulators are asked to explain their methods; and those regulators who do not currently use more sophisticated techniques (e.g. frontier benchmarking) are asked to explain the reasons behind their alternative choices. The main motivation for the survey is to build a better understanding of the factors that 
influence choice of methods, i.e. those that may encourage or discourage the adoption of advanced benchmarking techniques. We analyse the survey responses by constructing a best practice index and assigning scores to each country for electricity and gas regulation separately. We use the best practice scores to simplify cross-country comparison and to offer some general conclusions on trends in the application of efficiency analysis internationally.

\section{Advanced benchmarking methods}

There are various techniques that can be used to measure the efficiency of network (and other) companies and to derive suitable benchmarks for incentive regulation. The efficiency analysis literature, both theoretical and empirical, is now vast and associated benchmarking techniques have been applied in a wide variety of settings. The underlying interest in measuring efficiency is the desire to compare performance of different units and to identify sources of efficiency or inefficiency (Lovell, 1993). The aim of network regulators is to use this information to design policies that improve the performance of network companies by reducing inefficiency, both technical and allocative. Although the overall aims are clear, the means of achieving them are often not so clear. Regulators face the problem of choosing among methods that may produce very different results (Farsi et al., 2007). Furthermore, the regulatory process is an evolutionary one with choice of methods often varying over time and across countries and sectors (Agrell and Bogetoft, 2004).

We can divide the main existing benchmarking methods into two categories: frontier-based and average benchmarking. The former computes or estimates the efficient performance frontier by identifying best practice; the latter estimates measures of average performance. Frontier methods have a stronger focus on performance variations between firms and are often used to set firm-specific requirements (so-called firm specific $X$-factors). This approach is often suited to early stages of regulatory reform when reducing the performance gap among utilities is a central objective. Average benchmarking (and the setting of a common $X$-factor) may be more suitable when firms have relatively similar costs (Jamasb and Pollitt, 2001). In our survey we are mainly concerned with frontier methods due to their focus on performance variation. In particular, we aim to assess whether recent advances in frontier-based techniques have been incorporated into regulatory processes internationally.

The development of frontier-based benchmarking methods for efficiency analysis begins with the influential work of Farrell (1957) who proposed estimating an idealised frontier against which to compare existing firm performance. The main frontier methods currently in use are data envelopment analysis (DEA), corrected ordinary least squares (COLS) and stochastic frontier analysis (SFA). DEA is the main mathematical programming method; and COLS and SFA are both econometric methods. Although there are various models that can be used (e.g. constant returns to scale and variable returns to scale), the original idea of DEA as espoused by Charnes et al. (1978) was to compute a non-parametric, efficient frontier from input and output firm-level data. Efficiency measures can then be calculated for each of the firms relative to the frontier. Many different DEA models have appeared in the literature since and advances in theory and application continue to be made (Cook and Seiford, 2009). 
One of the main advantages of DEA is that the production or cost function does not need to be specified. By contrast, econometric methods such as COLS and SFA can be vulnerable to functional specification errors. Both COLS and SFA estimate efficiency scores. COLS assumes that all deviations from the frontier are due to inefficiency. SFA, on the other hand, recognises that stochastic errors may contribute to the measurement of inefficiencies. Introducing another random variable to account for statistical noise can overcome this obstacle in estimating the stochastic production frontier (Coelli et al., 2005). This allows for a distinction to be made between the effects of noise and the effects of inefficiency; one of the main advantages of the stochastic approach over programming approaches like DEA (Lovell, 1993). Process/activity benchmarking is an alternative to frontier-based methods of measuring efficiency and comparing performance against best practice. A bottom-up methodology is typically used to evaluate various aspects of business processes and to calculate optimal costs and efficiency (Farsi et al., 2007). The focus is on relative efficiency and relative costs and may include crossindustry comparisons. Process benchmarking can be a pragmatic alternative to frontier methods, for example when data limitations prevent their application. We refer to this subset of techniques: DEA, COLS, SFA and process/activity as advanced for the purposes of our study.

\section{The Survey}

Our survey was conducted electronically between June and October 2008 in both English and Spanish. Representatives from energy regulatory agencies around the world were invited to participate online using a dedicated survey website. Representatives were contacted by email and/or by phone using publicly available contact information; some specific contacts at regulatory agencies were suggested by Electricity Policy Research Group contacts in the relevant countries. In several countries, network regulation is carried out separately for electricity and gas. In these cases, contact was initiated with representatives from each regulatory agency.

When interpreting the results of the survey, it is important to remember that the answers may reflect not only the actual use of certain techniques and processes in a regulatory jurisdiction but also the level of consciousness among staff of the details of their use. We have sought to involve regulatory staff from departments that deal directly with tariffs and pricing in order to minimise errors in the responses. We have chosen this approach rather than a survey of public domain information, because we are interested in the inner workings of regulatory agencies vis-à-vis benchmarking methods and this includes internal knowledge and understanding. ${ }^{3}$

The survey questions fall into two main categories. The first set of questions relates to the specific benchmarking techniques used for electricity and gas transmission and distribution, as well as the process of choosing these techniques; the second category involves a closer look at the benchmarking analysis process, including the types of software used, adjustments for uncertainty and the

\footnotetext{
${ }^{3}$ Where any anomalies appeared in the survey responses, we have asked for clarifications from regulatory staff rather than consulting external sources.
} 
incorporation of environmental factors. A mixture of closed and open questions is used throughout the survey in order to give regulators the opportunity to expand on their individual experiences where necessary to offer further insights on the reasons behind a regulator's choice of efficiency analysis technique.

\subsection{Choice of benchmarking techniques}

Incentive regulation usually involves some form of benchmarking of actual versus a measure of reference performance. In our survey, we first ask regulators to specify whether they use benchmarking techniques to set regulated prices or revenue for any of their utilities (Question 3). Regulators are prompted with a list of techniques to answer this question: data envelopment analysis (DEA); corrected ordinary least squares (COLS); stochastic frontier analysis (SFA); and process/activity benchmarking. The first three are examples of frontier-based methods; the last is a non-frontier method that focuses on relative costs and may also involve cross-industry comparisons. The overall aim here is to investigate how many countries are using the latest advances in benchmarking techniques and to examine if there is any convergence towards a 'best practice' technique for each industry. There is a lot of experience in using benchmarking techniques, particularly among countries that have led the way in electricity and gas sector reforms (e.g. UK, Norway and Australia). We would expect to see most countries now using some form of benchmarking or at least considering its adoption.

An open question is also posed to allow regulators to identify other techniques which may have been used and to explain what was being benchmarked (Question 4). Regulators are then asked to identify which of the listed methods (DEA, COLS, SFA or process/activity benchmarking) were used as part of the most recent price review process and what was being benchmarked for each category of regulated company (Questions 5 and 6). ${ }^{4}$ We are particularly interested here in identifying the characteristics of those countries where sophisticated benchmarking techniques are implemented, i.e. if it is predominantly countries with large numbers of regulated companies that adopt the most advanced methods, or if there are also examples of countries with a limited number of companies that supplement national with international data. Also of interest is the extent to which regulators are using an integrated benchmarking model, i.e. a model that uses one measure of total expenditure - i.e. capital and operating expenditure (Totex) - rather than a model based on operating expenditure (Opex) only. An integrated model can better reflect the trade-offs between Opex and Capex from an economic efficiency perspective (Jamasb and Pollitt, 2007).

A series of three open questions follows where regulators who do not use benchmarking techniques are asked to explain the rationale behind their choice (Question 7); and all regulators are asked to identify any other benchmarking techniques that were considered (Question 8) and to explain why these

\footnotetext{
${ }^{4}$ The timing of the survey is important for some of the respondents. For example, responses for Germany refer to the most recent price review and do not reflect changes to the regulatory process that have been made since then. These changes came into force in January 2009, after our survey was conducted. Iceland's response includes some information on its revised regulatory process but the techniques mentioned had not yet been applied at the time of the survey.
} 
techniques were not adopted (Question 9). Here, we are aiming to identify how regulators have considered their options and to see if and why regulators may have ruled out alternative approaches. Given the options available to regulators and the important implications for efficiency scores of using different benchmarking techniques, we would expect regulators to experiment before deciding on a model to employ.

Table 1: Survey Questions

\begin{tabular}{c|c} 
Question & Options \\
\hline $1 . \quad$ Number of regulated companies &
\end{tabular}

2. Starting year and length of price/revenue control review period for each set of regulated companies

Choice of benchmarking techniques

3. Do you use benchmarking techniques in order to set regulated prices/revenue for any of your utilities? E.g. Data Envelopment Analysis (DEA); Corrected Ordinary Least Squares (COLS); Stochastic Frontier Analysis (SFA); Process/Activity Benchmarking

\begin{tabular}{l|l} 
Yes \\
No \\
Other
\end{tabular}

4. If none of the above techniques are considered, which benchmarking techniques have you used? What was being benchmarked? (e.g. operating expenditure, capital expenditure)

5. Considering your most recent set of price reviews, which benchmarking techniques have you used as part of the process? (You can choose more than one answer for each option)

$\mid \begin{array}{ll}\text { Not Applicable } & \text { DEA } \\ \text { COLS } & \text { Process/Act } \\ \text { SFA } & \text { Benchmark } \\ \text { Operating expenditure (Opex) only } \\ \text { Capital expenditure (Capex) only } \\ \text { Total expenditure (Opex + Capex) } \\ \text { Insert Remark } \\ \text { Not Applicable }\end{array}$

7. Please explain why you do not use any benchmarking techniques to set regulated prices/revenue for your utilities.

8. In addition to those mentioned above, were there any other benchmarking techniques which were considered but did not form part of the formal efficiency assessment process?

9. If there were any other techniques in the previous question that did not form part of the formal efficiency assessment process, why were they not used?

Benchmarking analysis process

10. For the techniques actually used as part of the formal efficiency assessment process, was the analysis carried out inside the regulatory agency? Please explain.

11. Where outside consultants were used, what was their specialism and did they involve academic experts, or international experts? (You can choose more than one answer for each option)

\begin{tabular}{|ll} 
Specialism & Type of Expert \\
Economics & Not Applicable \\
Engineering & Academic \\
Law & Other Professional
\end{tabular}


12. Where efficiency analysis was undertaken in house, what analysis software did you use? (You can choose more than one answer)

13. For each of your regulated group of firms, did the analysis specified in the most recent set of price reviews involve: (You can choose more than one answer)

\begin{tabular}{|c|c|}
\hline \multirow[t]{2}{*}{ Other } & Local \\
\hline & International \\
\hline DEAFrontier & EMS \\
\hline OnFront & Frontier V4.1 \\
\hline LIMDEP & FEAR/R \\
\hline Frontier Analyst & NLOGIT \\
\hline DEAP & Other, please specify \\
\hline \multicolumn{2}{|c|}{$\begin{array}{l}\text { Confidence interval analysis (e.g. } \\
\text { bootstrapping for DEA) }\end{array}$} \\
\hline \multicolumn{2}{|c|}{$\begin{array}{l}\text { Specific adjustment for uncertainty (e.g. } \\
\text { comparison against upper quartile) }\end{array}$} \\
\hline $\begin{array}{l}\text { Tests for well-bel } \\
\text { montonicity of cc }\end{array}$ & $\begin{array}{l}\text { functional form (e.g. } \\
\text { ction) }\end{array}$ \\
\hline
\end{tabular}

14. If you made a specific adjustment for uncertainty (e.g. comparison against upper quartile), please briefly describe the nature of the adjustment.

15. Did the analysis specified in the most recent set of price reviews also involve: (You can choose more than one answer)

16. In light of the previous question outline any problems you face with using the following type of data for benchmarking.

17. Have you incorporated environmental factors (e.g. weather, age of assets, customer density) into your assessment of the efficiency of regulated companies?

18. How did you incorporate environmental factors into your assessment of the efficiency of regulated companies?

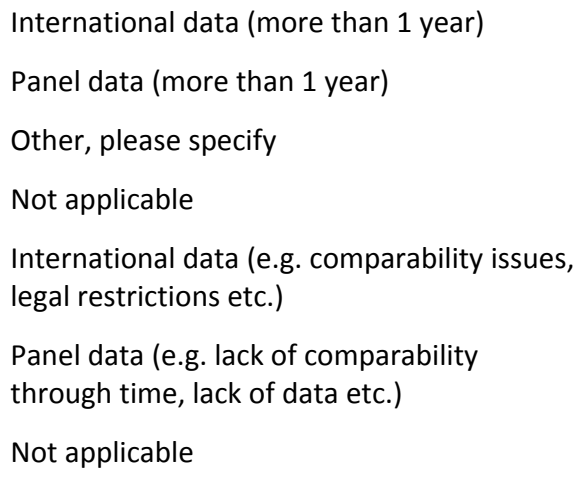

Second stage analysis in DEA

Z variables in SFA

Supplementary revenue adjustments

Other, please specify

19. Where more than one benchmarking technique was used to assess efficiency how was the efficiency for the purposes of regulated prices/revenue selected (e.g. highest efficiency score, subjective judgement etc.)?

20. For the final benchmarked efficiency score, how much and over what period was the measured inefficiency expected to be reduced (e.g. $50 \%$ over 5 years)?

21. Please comment on the extent to which you think it is practical or desirable that regulators should make use of the latest advances in efficiency analysis techniques. 


\subsection{Benchmarking analysis process}

The second part of the survey delves into the details of the analysis process. We ask those regulators who currently use various benchmarking techniques a series of questions; again, a mixture of closed and open questions is used. To start with, the general approach adopted for the analysis is investigated. Regulators are asked to explain whether the efficiency assessment was conducted in-house and to comment on this process (Question 10). Where external consultants have been engaged, regulators are asked to indicate their specialism and type (Question 11); and where in-house analysis has been undertaken to indicate the type of software used (Question 12).

Regulators increase their options substantially by contracting external experts, however internal involvement from the agency is important so that the analysis, results and any subsequent decisions can be fully understood internally. We would expect most countries to have a mixture of external and internal involvement and would consider this to be best practice. By looking at the specialism of external consultants, we can try to understand if there is a tendency in some countries towards specialties other than economics; this may contribute to biases in the use of advanced benchmarking techniques. Smaller agencies may be constrained by limited resources so it will be interesting to see if size has an impact on the choice to conduct internal or external analyses and how this may affect the sophistication of the techniques chosen (Domah et al., 2002; Pollitt and Stern, 2009 note the problem of regulatory capacity).

There is a wide variety of software packages available for efficiency analysis. Some, like LIMDEP, Frontier Analyst and DEAFrontier must be purchased; while others, especially DEAP, EMS and Frontier V4.1 are available free of charge ${ }^{5}$. Using packages that are freely available to others (companies and other stakeholders) promotes transparency by allowing for analysis and results to be replicated and critiqued at a later stage.

The next set of questions focuses on understanding how regulators across countries have overcome some of the challenges of using benchmarking methods in such a variety of contexts. Here we draw inspiration from Lovell (2006) who identifies a number of elements of best practice in the conduct of efficiency analysis. Lovell lists using the following: DEA, SDEA, COLS or SFA ${ }^{6}$; large and high-quality datasets; panel data; bootstrapping/confidence intervals; quality, environmental and input price variables; and consistency with non-frontier methods. Four main areas are investigated in the survey: uncertainty and bias surrounding efficiency estimates (Questions 13 and 14); data issues (Questions 15 and 16); environmental factors (Questions 17 and 18); and the selection of final efficiency scores

\footnotetext{
${ }^{5}$ Links to all available software packages mentioned in our survey are as follows: DEAFrontier: http://www.deafrontier.com/; DEAP: http://www.uq.edu.au/economics/cepa/deap.htm; EMS: http://www.wiso.uni-dortmund.de/lsfg/or/scheel/ems/; FEAR/R: http://business.clemson.edu/Economic/faculty/wilson/Software/FEAR/fear.html; Frontier Analyst: http://www.banxia.com/frontier/; Frontier V4.1: http://www.uq.edu.au/economics/cepa/frontier.htm; LIMDEP: http://www.limdep.com/; NLOGIT: http://www.limdep.com/features/whatsnew nlogit.php ${ }^{6}$ DEA: Data Envelopment Analysis; SDEA: Stochastic Data Envelopment Analysis; COLS: Corrected Ordinary Least Squares; SFA: Stochastic Frontier Analysis
} 
(Questions 19 and 20). We are interested in particular in understanding the extent to which regulators across countries are keeping up with emerging best practice in dealing with these issues, as indicated by Lovell (2006).

Efficiency measures are increasingly being used by regulators to incentivise minimum cost use of resources; however estimates of efficiency are subject to uncertainty and to a degree of bias.

Bootstrapping for DEA is one way of dealing with issues of uncertainty. The process aims to reduce the sensitivity of results to sample composition by using the given sample to generate a set of bootstrap samples; from this set estimates of relevant statistics, e.g. confidence intervals, can be derived. This can have important policy implications, for example not adjusting for uncertainty may incorrectly penalise firms that are far below the efficient frontier (Hawdon, 2003).

Collecting extensive and high-quality data is essential for the efficiency analysis process. Both national and international data are important; and in order to be able to make international comparisons, data collection processes, auditing and standardisation must be improved both within and across countries (Jamasb and Pollitt, 2003). We address this issue in the survey in order to see if and why countries may have encountered problems with panel and international data. Environmental factors such as weather and customer density are beyond the control of regulated companies but may affect their relative performance. These factors can be incorporated in different ways depending on the benchmarking techniques used; for example with DEA they can be accounted for by performing a second stage regression analysis of the efficiency scores (Giannakis et al., 2005; Yu et al., 2008)

Benchmarking should not be confined to one particular technique; instead regulators should make use of a combination of the latest techniques, e.g. DEA, COLS and SFA , to examine the consistency and robustness of results (Jamasb and Pollitt, 2001). This brings with it the challenge of selecting final efficiency scores for price/revenue regulation; and here the judgement of decision-makers is crucial. We would expect that where regulators have used multiple techniques, these would be used as tools for decision-making and would be supplemented with subjective judgement as to the weight placed on the results from each technique. Finally, we offer regulators the opportunity to give their perspectives on the practicality and desirability of using the latest efficiency analysis techniques (Question 21). Table 1 provides an overview of the complete set of survey questions.

\section{Survey Results}

\subsection{Choice of benchmarking techniques}

In total, we received 43 responses to our survey from 40 countries $^{7}$. Table 2 summarises the answers from each of our respondents to questions from the first section of the survey, i.e. questions 1 to 9 .

\footnotetext{
${ }^{7}$ Four responses were from Australian states and territories.
} 
Table 2: Choice of benchmarking techniques - Questions 1 to 9

\begin{tabular}{|c|c|c|c|c|c|c|c|c|c|c|c|c|c|}
\hline \multirow{3}{*}{$\begin{array}{l}\text { KEY: } \\
E=\text { electricity; } G=\text { gas } \\
D=\text { distribution; } T= \\
\text { transmission } \\
P / A=\text { process/activity }\end{array}$} & \multicolumn{4}{|c|}{$\begin{array}{l}\text { Number of regulated } \\
\text { companies (Q1) }\end{array}$} & \multicolumn{4}{|c|}{ Start date; length of review in years (Q2) } & \multirow{3}{*}{$\begin{array}{c}\text { Benchmarking } \\
\text { (DEA, COLS, SFA, } \\
\text { P/A) } \\
\text { (Q3) }\end{array}$} & \multicolumn{2}{|c|}{$\begin{array}{c}\text { Techniques in most recent price review } \\
\text { and benchmark (Qs } 4,5,6) \text {; if none, why } \\
\text { not? }(Q 7)\end{array}$} & \multicolumn{2}{|c|}{$\begin{array}{c}\text { Any other techniques considered? } \\
\text { (Q8) Why not part of formal process } \\
\text { (Q9) }\end{array}$} \\
\hline & \multicolumn{2}{|c|}{$E$} & \multicolumn{2}{|c|}{$G$} & \multicolumn{2}{|c|}{$E$} & \multicolumn{2}{|c|}{$G$} & & $E$ & $G$ & $E$ & G \\
\hline & D & $\mathrm{T}$ & D & $\mathbf{T}$ & D & $\mathbf{T}$ & D & $\mathbf{T}$ & & & & & \\
\hline \multicolumn{14}{|l|}{$E U$} \\
\hline Austria & 120 & 3 & 21 & 3 & $2005 ; 4$ & $2005 ; 4$ & $2008 ; 5$ & $2008 ; 5$ & Yes $(E+G)$ & \multicolumn{2}{|l|}{ COLS, DEA (T\&D) - Totex } & \multicolumn{2}{|c|}{$\begin{array}{l}\text { SDEA, SFA (T\&D) - SFA not possible due to } \\
\text { limited data }\end{array}$} \\
\hline Belgium & 27 & 1 & 1 & 20 & $2007 ; 1$ & $2007 ; 4$ & $2007 ; 1$ & $2007 ; 4$ & Yes $(E+G)$ & $\begin{array}{l}\text { DEA (T\&D); COLS, SFA } \\
\text { (T) - Totex (D); Opex } \\
\text { (T) }\end{array}$ & $\begin{array}{l}\text { DEA (T\&D) - Totex (D); } \\
\text { Opex (T) }\end{array}$ & & \\
\hline Cyprus & 1 & 1 & - & - & $2004 ; \mathrm{tbd}$ & $\begin{array}{l}\text { 2004; } \\
\text { tbd }\end{array}$ & - & - & No & \multicolumn{2}{|c|}{ Only 1 T\&D system operator } & & \\
\hline Czech Republic & 3 & 1 & 8 & 1 & $2005 ; 5$ & $2005 ; 5$ & $2005 ; 5$ & $2005 ; 5$ & No & \multicolumn{2}{|c|}{$\begin{array}{l}\text { Market not big enough - use int'I data for } E(T) \text { but } \\
\text { not sure if results will be used for regulation }\end{array}$} & & \\
\hline Denmark & 115 & 0 & 3 & 0 & $2006 ; 4$ & - & $2006 ; 4$ & - & Other $(E+G)$ & \multicolumn{2}{|c|}{ Unit cost model (D) - Opex and Capex } & & \\
\hline Estonia & 40 & 1 & 20 & 1 & $2008 ; 3$ & $2008 ; 3$ & & & Yes $(E+G)$ & \multicolumn{2}{|c|}{ COLS, P/A (T\&D) - Opex only } & & \\
\hline Finland & 102 & 1 & 31 & 1 & $2007 ; 4$ & $2007 ; 4$ & $2005 ; 4$ & $2005 ; 4$ & Yes (E); No (G) & $\begin{array}{l}\text { SFA, DEA (D); P/A (T) } \\
\text { - Totex but applied to } \\
\text { Opex only }\end{array}$ & NA & & \\
\hline Germany & 850 & 4 & $\begin{array}{r}70 \\
0\end{array}$ & 9 & $2008 ; 1$ & $2008 ; 1$ & $2008 ; 1$ & $2008 ; 1$ & No & \multicolumn{2}{|c|}{$\begin{array}{l}\text { Will start in January } 2009 \text { with DEA, SFA. Cost plus } \\
\text { regime now used to regulate prices }\end{array}$} & & \\
\hline Great Britain & 7 & 3 & 4 & 1 & $2005 ; 5$ & $2007 ; 5$ & $2008 ; 5$ & $2007 ; 5$ & Yes $(E+G)$ & \multicolumn{2}{|c|}{ COLS, DEA (D); P/A (T\&D) - Opex and Totex } & \multicolumn{2}{|c|}{$\begin{array}{l}\text { Expert assessment of unit costs, unit cost } \\
\text { benchmarking (T\&D); SFA but constrained } \\
\text { due to limited data }\end{array}$} \\
\hline Greece & 1 & 1 & 3 & 1 & $2007 ; 1$ & $2007 ; 1$ & & & No & \multicolumn{2}{|c|}{$\begin{array}{l}\text { Very late with reporting of unbundled accounts; } \\
\text { starting to design benchmarking methodology now }\end{array}$} & & \\
\hline Hungary & 6 & 1 & 10 & 1 & $2005 ; 4$ & $2005 ; 4$ & $2006 ; 4$ & $2006 ; 4$ & Yes $(E+G)$ & \multicolumn{2}{|c|}{$\mathrm{P} / \mathrm{A}(\mathrm{T} \& \mathrm{D})$} & & $\begin{array}{l}\text { Smooth average } \\
\text { (D) }\end{array}$ \\
\hline Ireland & 1 & 2 & 1 & 1 & $2005 ; 5$ & $2005 ; 5$ & $\begin{array}{l}2007 / 08 \\
5\end{array}$ & $\begin{array}{l}2007 / 08 \\
5\end{array}$ & $\begin{array}{l}\text { Yes (E) and Other } \\
\text { (G) }\end{array}$ & $P / A(T \& D)$ & $\begin{array}{l}\text { Bottom up \& top down } \\
\text { (T\&D) - Opex }\end{array}$ & & Yes (T\&D) \\
\hline Lithuania & 1 & 2 & 5 & 1 & $2007 ; 3$ & $2007 ; 3$ & $2005 ; 3$ & $2005 ; 3$ & No & \multicolumn{2}{|c|}{$\begin{array}{l}\text { Limited number of companies in E \& G; no } \\
\text { international data }\end{array}$} & & \\
\hline Luxembourg & 7 & 1 & 4 & 1 & $2006 ; 1$ & $2006 ; 1$ & $2006 ; 1$ & $2006 ; 1$ & No & \multicolumn{2}{|l|}{ Cost plus regime used } & & \\
\hline Netherlands & 8 & 1 & 9 & 1 & $2008 ; 3$ & $2008 ; 3$ & $2008 ; 3$ & $2006 ; 4$ & Yes (E); No (G) & $\begin{array}{l}\mathrm{DEA}(\mathrm{T})-\text { Totex, only } \\
\text { part included }\end{array}$ & NA & NA & NA \\
\hline
\end{tabular}




\begin{tabular}{|c|c|c|c|c|c|c|c|c|c|c|c|c|c|}
\hline Poland & 14 & 1 & 6 & 1 & & & & & Other (E); No (G) & $\begin{array}{l}\text { Bayesian random } \\
\text { effect model in cost } \\
\text { efficiency analysis (D) }\end{array}$ & NA & $\begin{array}{l}\text { DEA, COLS (D) - small } \\
\text { sample }\end{array}$ & \\
\hline Portugal & 3 & 3 & 11 & 1 & $2006 ; 3$ & $2006 ; 3$ & $\begin{array}{l}2007 / 200 \\
8 ; 3\end{array}$ & $\begin{array}{l}2007 / 200 \\
8 ; 3\end{array}$ & Yes (E); No (G) & SFA (D) - Opex only & NA & NA & NA \\
\hline Slovenia & 5 & 1 & 17 & 1 & $2006 ; 3$ & $2006 ; 3$ & $2008 ; 1$ & $2008 ; 1$ & Yes (E); No (G) & $\begin{array}{l}\text { DEA, P/A (D) - Opex } \\
\text { only }\end{array}$ & NA & NA & NA \\
\hline Spain & - & - & 25 & 9 & & & $\begin{array}{l}2008 ; 3 \\
\text { months }\end{array}$ & $\begin{array}{l}2008 ; 3 \\
\text { months }\end{array}$ & Yes (G) & - & $\mathrm{P} / \mathrm{A}(\mathrm{T} \& \mathrm{D})$ & & \\
\hline Sweden & 171 & 6 & 5 & 2 & & & & & No & \multicolumn{2}{|c|}{$\begin{array}{l}\text { Ex-post type regulation used - for } \mathrm{G} \text { new model } \\
\text { being developed; for E will change to ex-ante with } \\
\text { revenue caps }\end{array}$} & & \\
\hline \multicolumn{14}{|l|}{ Rest of Europe } \\
\hline Croatia & 1 & 1 & 38 & 1 & $2008 ; 1$ & $2008 ; 1$ & 2008 & 2008 & No & \multicolumn{2}{|c|}{ Cost of service method used } & & \\
\hline Iceland & 7 & 1 & & & $2007 ; 3$ & $2007 ; 3$ & & & $\begin{array}{l}\text { Yes (E) but not yet } \\
\text { applied }\end{array}$ & $\begin{array}{l}\text { DEA (T\&D) - Opex } \\
\text { only }\end{array}$ & - & & \\
\hline Norway & 158 & 1 & - & - & $2007 ; 5$ & $2007 ; 5$ & & & Yes (E) & $\begin{array}{l}\text { DEA and SFA (D) - } \\
\text { Totex } \\
P / A(T)\end{array}$ & - & $\begin{array}{l}\text { Considered DEA and SFA } \\
\text { as better tools than } \\
\text { COLS }\end{array}$ & \\
\hline Romania & & & 65 & 1 & & & $2008 ; 5$ & $2007 ; 5$ & No & \multicolumn{2}{|c|}{$\begin{array}{l}\text { Time frame for collecting data too short; unreliable } \\
\text { data; cost plus method used for all but } 8\end{array}$} & & \\
\hline \multicolumn{14}{|l|}{ Latin America } \\
\hline Argentina & 3 & 7 & - & - & & $1998 ; 5$ & & & Yes (E) & DEA (T) - Opex only & - & & \\
\hline Bolivia & 6 & 3 & - & - & $2007 ; 4$ & $\begin{array}{l}2008 ; 6 \\
\text { months }\end{array}$ & & & Yes (E) & $\mathrm{P} / \mathrm{A}(\mathrm{T} \& \mathrm{D})$ & - & $\begin{array}{l}\text { NA - lack of comparable } \\
\text { data }\end{array}$ & \\
\hline Brazil & 77 & 46 & - & - & $2007 ; 4$ & $2005 ; 4$ & & & Yes (E) & DEA (T) - Opex only & - & $\begin{array}{l}\text { Acceptable commercial } \\
\text { loss }\end{array}$ & \\
\hline Chile & 34 & 53 & 1 & 0 & $2004 ; 4$ & $2007 ; 4$ & $2006 ; 5$ & 0 & Other $(E+G)$ & \multicolumn{2}{|c|}{$\begin{array}{l}\text { Simulation of most efficient company, taking } \\
\text { actual company installations into account (D) - } \\
\text { Investment, O\&M, admin, customer service }\end{array}$} & & \\
\hline Colombia & 31 & 7 & 32 & 8 & $2002 ; 5$ & $2000 ; 5$ & $2004 ; 5$ & $2002 ; 5$ & Yes $(E+G)$ & $\begin{array}{l}\text { DEA (T\&D) - Capex } \\
\text { only }\end{array}$ & DEA, P/A (T) - Capex only & $\begin{array}{l}\text { Comparison of capital } \\
\text { costs (T\&D) }\end{array}$ & \\
\hline Dominican Republic & 3 & 1 & - & - & $\begin{array}{l}2008 ; 1 \\
\text { month }\end{array}$ & $\begin{array}{l}2008 ; 1 \\
\text { month }\end{array}$ & & & No & \multicolumn{2}{|c|}{$\begin{array}{l}\text { Prices subsidized and have not changed since } \\
\text { January } 2006\end{array}$} & & \\
\hline Ecuador & 20 & 1 & - & - & $2007 ; 1$ & $2007 ; 1$ & & & Other (E) & $\begin{array}{l}\text { Percentage caps } \\
\text { (T\&D) - Capex and } \\
\text { Opex }\end{array}$ & & \multicolumn{2}{|c|}{$\begin{array}{l}\text { Polynomial formula (D); units of property } \\
\text { and standard costs }(T) \text { - Polynomial very } \\
\text { inflexible }\end{array}$} \\
\hline El Salvador & 6 & 1 & - & - & $2007 ; 5$ & $2008 ; 1$ & & & No & \multicolumn{2}{|c|}{$\begin{array}{l}\text { Charges based on simulating most efficient } \\
\text { company; specific methodologies for defining } \\
\text { tariffs for each case }\end{array}$} & & \\
\hline Mexico & 2 & 1 & 22 & $\begin{array}{r}16 \\
2\end{array}$ & $1996 ; 10$ & 1996; 10 & $\mathrm{NA} ; 5$ & $\mathrm{NA} ; 5$ & No (E) Yes (G) & & $\begin{array}{l}\text { COLS (T\&D); DEA (D) - } \\
\text { Totex }\end{array}$ & SFA (D) & DEA, COLS (D) \\
\hline
\end{tabular}




\begin{tabular}{|c|c|c|c|c|c|c|c|c|c|c|c|c|c|}
\hline Nicaragua & 4 & 1 & & - & $2008 ; 1$ & $2007 ; 5$ & & & No & \multicolumn{2}{|c|}{$\begin{array}{l}\text { System different to rest of Central American region } \\
\text {-difficult to make comparisons }\end{array}$} & & \\
\hline Panama & 3 & 1 & - & - & $2006 ; 4$ & $2005 ; 4$ & & & Yes (E) & & & & \\
\hline Peru & 21 & 5 & 1 & 1 & $2009 ; 4$ & $2009 ; 4$ & $2008 ; 4$ & - & Yes (E); No (G) & $\mathrm{P} / \mathrm{A}(\mathrm{D}) ; \mathrm{NA}(\mathrm{T})$ & & $\begin{array}{l}\text { Yardstick and simulation } \\
\text { of most efficiency } \\
\text { company (D); adapted } \\
\text { economic system (T) }\end{array}$ & \\
\hline Uruguay & 1 & 1 & 2 & 2 & & $2007 ; 1$ & $2002 ; 6$ & 2002 & No & \multicolumn{2}{|c|}{$\begin{array}{l}\text { Regulatory framework does not specify this; } \\
\text { yardstick regulation is referred to. Benchmarking } \\
\text { could be used in gas }\end{array}$} & & \\
\hline Venezuela & 11 & 2 & - & - & $\begin{array}{l}2002 ; \\
\text { indefinite }\end{array}$ & $\begin{array}{l}\text { 2002; } \\
\text { indefinit } \\
\text { e }\end{array}$ & & & Yes (E) & $\mathrm{P} / \mathrm{A}(\mathrm{T} \& \mathrm{D})$ & & & \\
\hline \multicolumn{13}{|l|}{ Australasia } & \\
\hline New Zealand & 28 & 1 & 2 & 0 & $2004 ; 5$ & $2004 ; 5$ & $2005 ; 5$ & - & Yes (E); № (G) & $\begin{array}{l}\text { P/A (D); NA (T) - } \\
\text { Opex only (MFTP } \\
\text { used) }\end{array}$ & & $\begin{array}{l}\text { DEA, SFA }(D) \text { - quality of } \\
\text { data unsuitable; inability } \\
\text { to easily reproduce } \\
\text { results }\end{array}$ & \\
\hline Northern Territory & 1 & 0 & & - & $2004 ; 5$ & & - & & Other - & \multicolumn{2}{|c|}{$\begin{array}{l}X \text { factor for CPI-X price path based on experience } \\
\text { in other Australian jurisdictions (D) - Opex }\end{array}$} & & \\
\hline South Australia & 1 & 0 & 1 & 0 & $2005 ; 5$ & - & $2006 ; 5$ & - & No & & & & \\
\hline Tasmania & 1 & 0 & & - & $\begin{array}{l}2007 ; 18 \\
\text { months }\end{array}$ & & - & & Other - & \multicolumn{2}{|c|}{$\begin{array}{l}\text { Partial factor, cost comparisons (D) - Opex and } \\
\text { Capex }\end{array}$} & & \\
\hline Western Australia & 1 & 1 & 1 & 3 & $2006 ; 3$ & $2006 ; 3$ & $2005 ; 5$ & $2005 ; 5$ & No & \multicolumn{2}{|c|}{$\begin{array}{l}\text { Cost of service used; benchmarking not commonly } \\
\text { used by other Australian regulators - data not } \\
\text { readily available }\end{array}$} & & \\
\hline
\end{tabular}


These questions focus firstly on the characteristics of the sectors and review periods; and secondly on the choice of benchmarking techniques and the rationale behind this choice.

\subsubsection{Who uses benchmarking techniques?}

Of the 43 regulators surveyed, $51 \%$ use frontier-based benchmarking methods (DEA, COLS, SFA) or process/activity benchmarking for either electricity or gas, and in some cases for both. A further $35 \%$ do not use benchmarking methods at all and $14 \%$ use other forms of benchmarking than those listed (see Figure 1). A simple look at this breakdown, however, does not tell us the full story. If we look at the rationale given by those who do not currently use benchmarking techniques, 6 of the 15 regulators explain that they are in the process of implementing (Germany and Sweden), are partially using (Czech Republic and Romania), or are starting to consider the use of benchmarking techniques (Greece and Luxembourg). This leaves only 9 out of 43 regulators (21\%) who do not use and are not considering the use of benchmarking in regulating either their electricity or gas companies.

Figure 1: Use of benchmarking techniques for Electricity or Gas

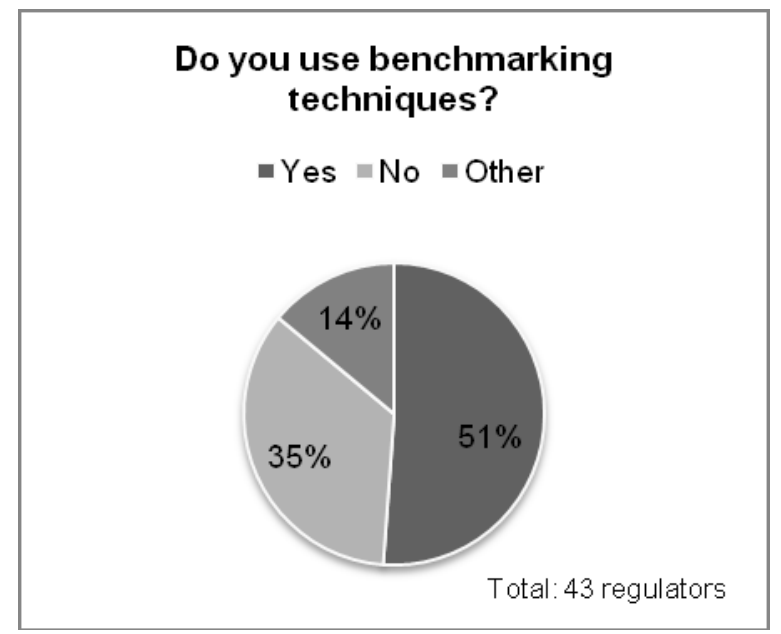

Breaking down these results even further, we can see a number of patterns emerging if we look at the responses by industry, size and region. Of the total 42 responses for electricity regulation, $48 \%$ use advanced benchmarking methods; and of the 29 responses for gas regulation, only $28 \%$ use these methods. It does not necessarily follow that if the latest benchmarking techniques are used by a regulator for electricity companies that this will also be the case for gas regulation. There are a number of examples where the same regulator is responsible for both electricity and gas network companies; however advanced benchmarking methods are used for the former and not the latter. Finland, Ireland, the Netherlands, New Zealand, Peru, Portugal and Slovenia are all examples of this phenomenon. Mexico, by contrast, uses advanced techniques to benchmark gas companies but not electricity.

While there are signs that on the whole advanced benchmarking techniques are more prevalent in the electricity industry, there are factors other than industry type at work. We would expect the number of regulated companies to also have an impact on the choice of methodology. In general, it is easier for countries with larger numbers of distribution and transmission companies to compare and benchmark 
performance across these companies than for those with limited numbers. Smaller countries with smaller numbers of firms have the option to supplement limited national data with international data, however there are further challenges involved with this approach that we will explore in the next section.

For the electricity industry, $65 \%$ of regulators who use advanced benchmarking methods are responsible for seven or more distribution companies and $35 \%$ for less than seven ${ }^{8}$. For those who do not use any benchmarking techniques, only $31 \%$ are responsible for seven or more distribution companies ${ }^{9}$. For the gas industry, 6 out of 8 regulators who use advanced techniques (75\%) regulate 7 or more distribution companies. The same trend is evident for those who do not use any benchmarking techniques: 10 out of $18(56 \%)$ regulate less than 7 distribution companies. This confirms our expectation that the majority of both gas and electricity regulators who use advanced benchmarking methods are in fact countries or regions with larger numbers of regulated companies. The evidence also suggests, however, that there are several examples where countries with very few regulated companies have chosen to adopt advanced benchmarking techniques; this is particularly true of electricity regulation. Portugal, Slovenia and Panama are the main examples from our survey.

Some of the qualitative evidence from our survey suggests that the techniques used in a regulator's region may affect a regulator's ultimate choice of methodology. This type of neighbourhood effect may occur for a number of reasons. In the case of Western Australia, one of the primary reasons given for not using benchmarking is that other Australian regulators have not commonly used these techniques. This has an impact on the availability of data for comparative purposes and may place a limit on the options open to a regional regulator. If we look at the results from the EU by contrast, out of 20 countries that responded, 11 currently use the listed benchmarking techniques; 2 use other forms of benchmarking; 1 partially uses benchmarking; and 4 are planning to implement incentive based regulation. This leaves only 2 definite negatives and in both cases (Cyprus and Lithuania), the size of the market and limited data are given as the determining factors. The size limitation, however, is not seen as an insurmountable obstacle for other small countries in the EU -8 of the 20 respondents have less than 7 electricity distribution companies.

Of course, a regulator's choice of methods is constrained by a range of additional factors other than industry setting and region. Human resource constraints can be particularly significant in developing countries where there are large fixed costs involved in network regulation. Domah et al. (2002) and Pollitt and Stern (2009) show that these constraints are particularly serious when it comes to employing a sufficient number of experienced professional staff in regulatory agencies. This constraint may have an

\footnotetext{
${ }^{8}$ Seven was used as the size cut-off so as to compare countries with more or less distribution companies than Great Britain, where there are seven independent groups in the electricity distribution sector.

${ }^{9}$ Distribution companies are used as the size descriptor here. In most cases regulators who use advanced benchmarking techniques do so for both distribution and transmission companies; it is more likely in our sample for regulators to use advanced techniques for distribution and not for transmission than vice versa. Argentina, Brazil and the Netherlands are exceptions to this.
} 
impact on the choice of benchmarking methods; generally more complex methods require the use of more internal and possibly also external resources. Of the four lower-middle income countries in our sample, one regulator uses advanced benchmarking techniques (Bolivia); one uses an alternative form of benchmarking (Ecuador); and two do not use any benchmarking methods (El Salvador and Nicaragua). ${ }^{10}$ Just under less than half ( 8 out of 17 ) of the lower-income and upper-middle income countries (mainly in Latin America); and just over half (15 out of 26) of the high-income countries use advanced benchmarking in either electricity or gas. It is difficult to say for certain from this evidence whether human resource constraints have played a role in the speed with which advanced techniques are adopted. It may, however, be the case that human resource constraints are more important in determining the sophistication with which these techniques are applied rather than whether they are used. We will return to this issue at the end of Section 3.2 when we look more closely at the details of the analysis process.

\subsubsection{Which benchmarking techniques are used?}

For those regulators who used DEA, COLS, SFA or process/activity benchmarking in the most recent review period, process/activity benchmarking is the technique used most often in both the electricity and gas industries. Table 3 shows each of the techniques ranked according to the number of regulators using the technique in each industry, i.e. 1 denotes the technique used the most and 4 the least. As can be seen, there are strong similarities across industries. The main differences are: (1) SFA has not been used by any of the surveyed regulators in the gas industry; and (2) there is a stronger preference for DEA over COLS in the electricity industry than in gas. Ranking of techniques remains virtually the same if we look at distribution and transmission level by industry, although process/activity and DEA are tied in first position for electricity transmission; and the same number of regulators (four) uses each of process/activity, DEA and COLS to benchmark gas distribution companies.

Table 3: Question 5-Benchmarking techniques by industry

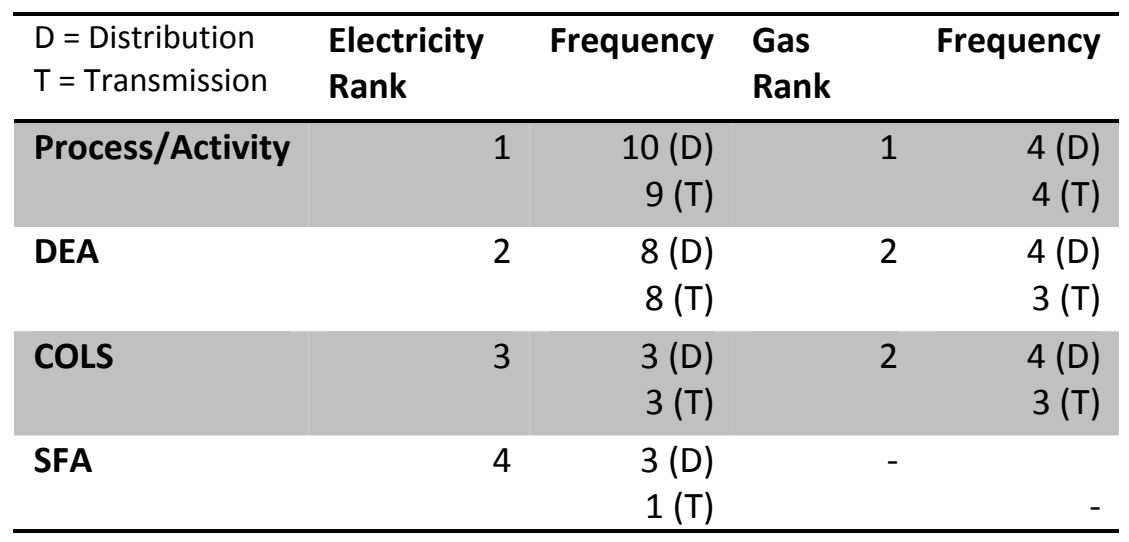

\footnotetext{
${ }^{10}$ We use the current World Bank classification of countries by income which is based on 2008 GNI per capita and calculated using the World Bank Atlas method. The groups are: low income, $\$ 975$ or less; lower-middle income, $\$ 976$ - $\$ 3,855$; upper-middle income, $\$ 3,856$ - $\$ 11,905$; and high income, $\$ 11,906$ or more. Further information can be found here: www.worldbank.org/data/countryclass/classgroups.htm
} 


\subsubsection{What was benchmarked?}

In using DEA, COLS or SFA, just over half of the regulators that responded (including both electricity and gas) benchmark Opex only in their models ( 9 out of 15); 7 use a Totex measure for benchmarking; and 1 uses Capex only (see Figure 2). Two regulators selected multiple responses for this question: the Belgian regulator explains that Totex is used for distribution and Opex only for transmission; and the British regulator uses measures of both Opex only and Totex.

Figure 2: Opex, Capex and Totex benchmarking

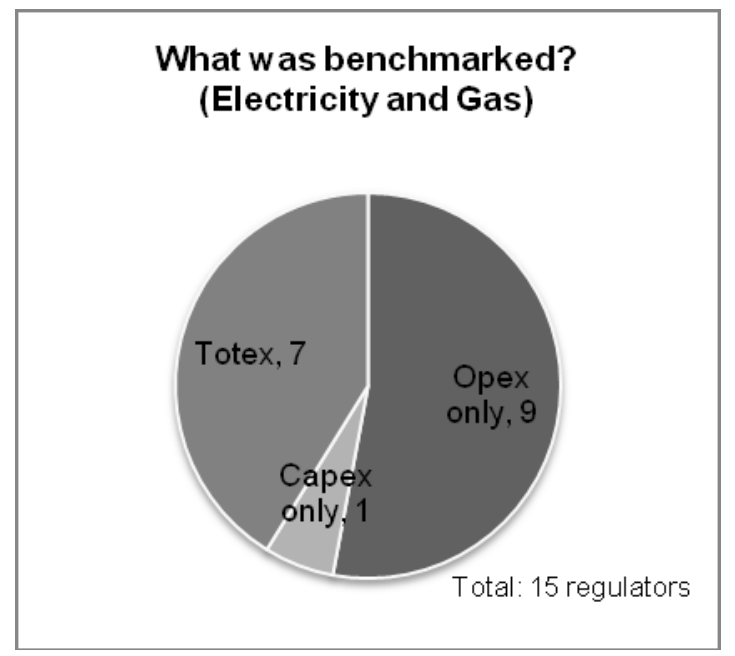

\subsubsection{Why is benchmarking not used?}

The main reasons given by regulators for not currently using benchmarking techniques, in response to Question 7, can be grouped into the following categories: (1) different methodology currently in place, e.g. cost of service, cost plus regime; (2) small sector size viewed as a barrier; (3) problems with or lack of data; (4) regulatory/legislative barriers; and (5) due to commence implementing or designing benchmarking methodology in the near future.

\subsubsection{Alternative approaches}

There are several countries that use alternative benchmarking models to the best practice techniques we investigate in detail in our survey. Although limited information is available in the survey on the details of these techniques, we can make a few general observations on their application. Most of the responses refer to benchmarking of electricity distribution companies (6 out of 7); in 4 out of 7 cases, Opex was benchmarked; and in the remaining three, both Opex and Capex were benchmarked.

In total, 11 countries reported considering other techniques than those formally included in the regulatory process. Of these, 9 ultimately decided to use some form of advanced benchmarking technique for either electricity or gas regulation. Interestingly, Mexico decided to implement DEA and COLS for the gas industry but ruled out implementing SFA for electricity distribution companies. The remaining two countries decided to implement alternative benchmarking techniques after some 
consideration of other options. Poland, for instance, considered DEA and COLS for electricity distribution but due to small sample size opted for a Bayesian random effect model instead.

\subsection{Benchmarking analysis process}

From the second set of survey questions, 10 to 21, we gain a more detailed understanding of the process undertaken by those regulators who have implemented advanced and other benchmarking techniques. This allows us to explore the quality of implementation and to investigate if there are any areas of weakness which may need to be addressed. Table 4 summarises the responses for questions 10 to 20 . The final open question, 21 , will be discussed separately.

\subsubsection{Who carries out efficiency analysis?}

Of the 22 responses to our question looking at the use of internal versus external analysis (Question 10), just over half of the respondents explained that the process involved a mixture of external consultants supported in some way by internal agency staff (see Figure 3). The remaining responses were split equally between those with internal only and external only analyses.

Figure 3: Internal/External Analysis

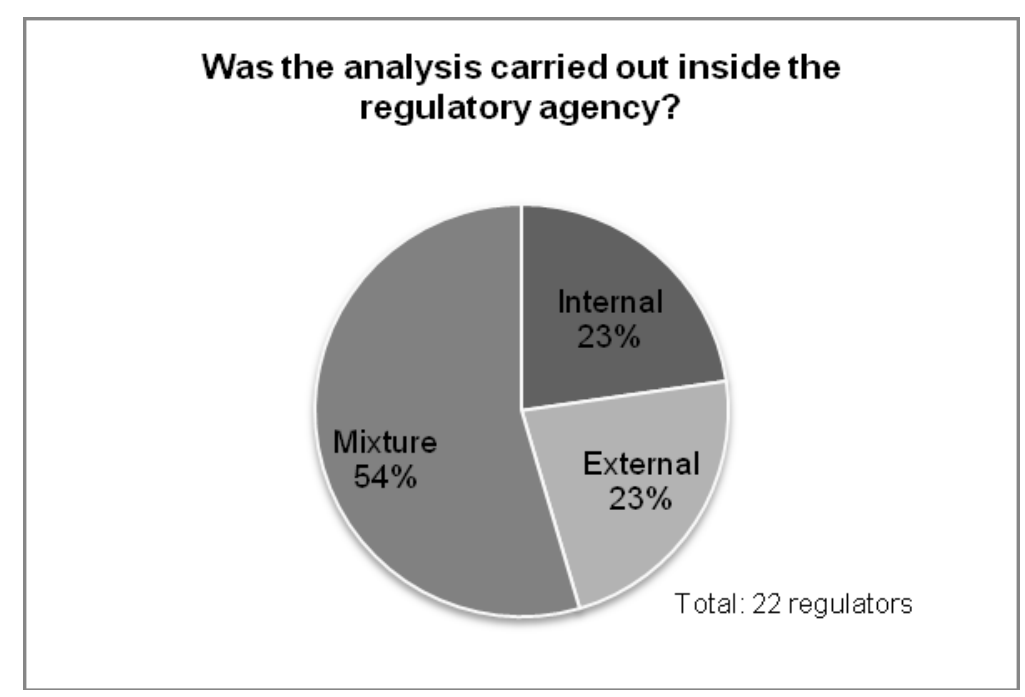

\subsubsection{Specialism of consultants}

For those regulatory agencies who engaged external consultants, the highest number of regulators identified economics as one of their consultants' specialisms, followed by engineering, as can be seen from Table 5. The majority of total respondents (16 out of 22 ) identified more than one specialism for the consultants engaged. Economics and Engineering was a popular combination, also featuring for 16 out of 22 regulators. Other specialists who were called on were: auditors, accountants and information systems (IS), property, insurance and productivity specialists. 
Table 4: Benchmarking analysis process - Questions 10 to 20

\begin{tabular}{|c|c|c|c|c|c|c|c|c|c|c|c|}
\hline & $\begin{array}{l}\text { Analysis } \\
\text { inside } \\
\text { agency? } \\
\text { (Q10) }\end{array}$ & $\begin{array}{l}\text { Consultant } \\
\text { specialism } \\
\text { (Consultant } \\
\text { type) (Q11) }\end{array}$ & $\begin{array}{l}\text { In-house } \\
\text { software } \\
\text { (Q12) }\end{array}$ & \multicolumn{2}{|c|}{$\begin{array}{l}\text { Uncertainty techniques } \\
\text { (Q13); Specific adjustment } \\
\text { (Q14) }\end{array}$} & \multicolumn{2}{|c|}{ Data used (Q15) } & $\begin{array}{l}\text { Problems with data } \\
\text { (Q16) }\end{array}$ & $\begin{array}{l}\text { Incorporate } \\
\text { environmental } \\
\text { factors? (Q17); } \\
\text { how? (Q18) }\end{array}$ & $\begin{array}{l}\text { Efficiency } \\
\text { score selection } \\
\text { (Q19) }\end{array}$ & $\begin{array}{l}\text { Inefficiency reduction } \\
(\mathrm{Q} 20)\end{array}$ \\
\hline KEY & \multicolumn{2}{|c|}{$\begin{array}{l}\mathrm{D} \text { - distribution } \\
\mathrm{T} \text { - transmission }\end{array}$} & \multicolumn{3}{|c|}{$\begin{array}{lc}\text { A - academic } & \text { I }- \text { international } \\
\text { OP - other professional } & \text { L - local } \\
\text { CIA - confidence interval analysis }\end{array}$} & \multicolumn{2}{|c|}{$\begin{array}{l}\text { I - International } \\
\text { P - Panel }\end{array}$} & & & & \\
\hline$E U$ & & & & Electricity & Gas & Electricity & Gas & & & & \\
\hline & & & & \multicolumn{4}{|c|}{ (refers to both $E$ and $G$ if response crosses both columns) } & & & & \\
\hline Austria & $\begin{array}{l}\text { Both within } \\
\text { and outside } \\
\text { agency }\end{array}$ & Economics (I) & $\begin{array}{l}\text { Frontier } \\
\text { Analyst }\end{array}$ & NA & NA & $\begin{array}{l}\text { Int'l and } \\
\text { Panel } \\
\text { (T\&D) }\end{array}$ & $\begin{array}{l}\text { Int'l and } \\
\text { Panel } \\
\text { (T\&D) }\end{array}$ & NA & $\begin{array}{l}\text { Yes; second stage } \\
\text { DEA; Model Network } \\
\text { Analysis (MNA) }\end{array}$ & $\begin{array}{l}\text { Weighted (E and } \\
\text { G; T\&D) }\end{array}$ & $\begin{array}{l}25.24 \% ; 8 \text { years }(\mathrm{E}- \\
\text { T\&D) } \\
25.94 \% ; 10 \text { years }(\mathrm{G}- \\
\text { T\&D) }\end{array}$ \\
\hline Belgium & $\begin{array}{l}\text { Yes, due to } \\
\text { time } \\
\text { constraints } \\
\text { (less than } \\
\text { two months } \\
\text { for the } \\
\text { reviews) }\end{array}$ & $\begin{array}{l}\text { Economics (A, } \\
\text { I); Engineering } \\
\text { (A, I); Law (A, } \\
\text { I) }\end{array}$ & $\begin{array}{l}\text { EMS (only } \\
\text { for } \\
\text { confirmatio } \\
\text { n of results) }\end{array}$ & \multicolumn{2}{|c|}{$\begin{array}{l}\text { CIA }(T \& D), \text { tests }(T \& D), \\
\text { adjustment }(T) \text { - compared } \\
\text { different methodologies }(E) ; \\
\text { sample of European and non- } \\
\text { European companies }(G)\end{array}$} & $\begin{array}{l}\text { Int'l and } \\
\text { Panel (T) }\end{array}$ & $\begin{array}{l}\text { Int'l and } \\
\text { Panel (T) }\end{array}$ & $\begin{array}{l}\text { Comparability issues }(\mathrm{I}) \text {; } \\
\text { very volatile malmquist } \\
\text { index from year to year }(\mathrm{P})\end{array}$ & $\begin{array}{l}\text { Yes; additional outputs } \\
\text { in DEA (restrict no. of } \\
\text { companies on frontier) }\end{array}$ & $\begin{array}{l}\text { Efficiency score } \\
\text { (E and G; D), } \\
\text { Efficiency score } \\
\text { and subjective } \\
\text { judgement (E and } \\
\text { G; T) }\end{array}$ & $\begin{array}{l}\text { Average } 10 \% \text {, max. } 29 \% \text {; } \\
5 \text { years }(\mathrm{E}-\mathrm{D} \text { ) } \\
\text { Average } 8 \% \text {; max. 29\%; } 5 \\
\text { years (G -D) }\end{array}$ \\
\hline Denmark & $\begin{array}{l}\text { Yes. For } \\
\text { initial data } \\
\text { collection } \\
\text { consulting } \\
\text { firm used. }\end{array}$ & $\begin{array}{l}\text { Other - } \\
\text { Auditors (L) }\end{array}$ & Excel & & & Panel (D) & & & Yes; Other & & \\
\hline Estonia & & $\begin{array}{l}\text { Economics (L); } \\
\text { Engineering } \\
\text { (L); Law (L) }\end{array}$ & Other & & & & & & & & \\
\hline Finland & $\begin{array}{l}\text { Methodology } \\
\text { and analysis } \\
- \\
\text { consultants; } \\
\text { final } \\
\text { estimations - } \\
\text { regulator. }\end{array}$ & $\begin{array}{l}\text { Economics and } \\
\text { Engineering } \\
\text { (A, OP, I, L) }\end{array}$ & $\begin{array}{l}\text { Frontier V } \\
4.1\end{array}$ & $\begin{array}{l}\text { CIA, tests, adjustment } \\
\text { (D) - final scores } \\
\text { adjusted by } 16 \% \\
\text { uncertainty factor }\end{array}$ & & $\begin{array}{l}\text { Panel } \\
\text { (T\&D) }\end{array}$ & & NA & $\begin{array}{l}\text { Yes; \% of underground } \\
\text { cables (proxy for areas) } \\
\text { and interruption time } \\
\text { (proxy for difficulty) }\end{array}$ & $\begin{array}{l}\text { Average of DEA } \\
\text { and SFA scores } \\
\text { (E; D) }\end{array}$ & $\begin{array}{l}\text { Average of } 18 \% ; 8 \text { years } \\
\text { (E - D) }\end{array}$ \\
\hline $\begin{array}{l}\text { Great } \\
\text { Britain }\end{array}$ & $\begin{array}{l}\text { Some carried } \\
\text { out in-house } \\
\text { and some by } \\
\text { different } \\
\text { consultants. }\end{array}$ & $\begin{array}{l}\text { Economics and } \\
\text { Engineering (L, } \\
\text { I); Other - IS, } \\
\text { property, } \\
\text { insurance } \\
\text { specialists (L, } \\
\text { I) }\end{array}$ & $\begin{array}{l}\text { FEAR/R; E- } \\
\text { Views; } \\
\text { Excel }\end{array}$ & \multicolumn{2}{|c|}{$\begin{array}{l}\text { Tests and adjustment (D) - } \\
\text { Used COLS with benchmark set } \\
\text { at upper quartile }\end{array}$} & Int'l (T) & Int'l (T) & $\begin{array}{l}\text { Different } \\
\text { accounting/business / } \\
\text { regulatory structures (I); } \\
\text { differences in accounting of } \\
\text { time including changes in } \\
\text { capitalisation policies, } \\
\text { differences in allocation } \\
\text { across activities (P) }\end{array}$ & $\begin{array}{l}\text { Yes; second stage } \\
\text { DEA; as part of } \\
\text { composite variable in } \\
\text { COLS }\end{array}$ & $\begin{array}{l}\text { Average of range } \\
\text { of techniques (E; } \\
\text { D); Judgement (E } \\
\text { and G; T); } \\
\text { Adjusted bottom- } \\
\text { up benchmarking } \\
\text { to be in line with } \\
\text { top-down (G; D) }\end{array}$ & $\begin{array}{l}100 \% \text { by beginning of new } \\
\text { period }(E \text { and } G-D)\end{array}$ \\
\hline
\end{tabular}




\begin{tabular}{|c|c|c|c|c|c|c|c|c|c|c|c|}
\hline Hungary & $\begin{array}{l}\text { With the help } \\
\text { of outside } \\
\text { experts. }\end{array}$ & $\begin{array}{l}\text { Economics } \\
\text { (OP); } \\
\text { Engineering } \\
\text { (OP, L); Law } \\
\text { (L) }\end{array}$ & & & & $\begin{array}{l}\text { Int'l and } \\
\text { Panel } \\
\text { (T\&D) }\end{array}$ & Panel (D) & & $\begin{array}{l}\text { Yes; supplementary } \\
\text { revenue adjustments }\end{array}$ & & $\begin{array}{l}\text { Mean of 2\%; } 1 \text { year (E and } \\
G-T \& D)\end{array}$ \\
\hline Ireland & $\begin{array}{l}\text { External } \\
\text { analysis with } \\
\text { internal } \\
\text { assistance }\end{array}$ & $\begin{array}{l}\text { Economics } \\
\text { (OP, L, I); } \\
\text { Engineering } \\
\text { (OP, L, I); } \\
\text { Other - } \\
\text { Accounting (I) }\end{array}$ & & Tests (T\&D) & & Int'l (T\&D) & $\begin{array}{l}\text { Int'l and } \\
\text { Panel } \\
\text { (T\&D) }\end{array}$ & $\begin{array}{l}\text { Difficulties in comparison } \\
\text { due to structure of asset } \\
\text { ownership/operation of T } \\
\text { network (I); legal restrictions } \\
\text { (I\&P) }\end{array}$ & Yes & NA & $\begin{array}{l}2.5 \% ; 5 \text { years }(G-D) \\
2 \% ; 5 \text { years }(G-T)\end{array}$ \\
\hline $\begin{array}{l}\text { Netherlan } \\
\text { ds }\end{array}$ & $\begin{array}{l}\text { Independent } \\
\text { consultant. }\end{array}$ & $\begin{array}{l}\text { Economics } \\
\text { (A); } \\
\text { Engineering } \\
(\mathrm{OP})\end{array}$ & & $\begin{array}{l}\text { Adjustment }(\mathrm{T})- \\
\text { confidence interval } \\
\text { derived and applied to } \\
\text { recent costs only }\end{array}$ & NA & $\begin{array}{l}\text { Int'l and } \\
\text { Panel (T) }\end{array}$ & - & $\begin{array}{l}\text { Comparability, legal issues, } \\
\text { data validation, differences in } \\
\text { TSO and admin. } \\
\text { organisations, quality issues } \\
\text { (I\&P) }\end{array}$ & $\begin{array}{l}\text { Yes; identify country } \\
\text { specific allowances }\end{array}$ & Judgement (E; T) & $20 \% ; 3$ years $(\mathrm{E}-\mathrm{T})$ \\
\hline Poland & $\begin{array}{l}\text { Analysis } \\
\text { prepared by } \\
\text { local } \\
\text { university } \\
\end{array}$ & $\begin{array}{l}\text { Economics (A, } \\
\mathrm{L})\end{array}$ & $\begin{array}{l}\text { DEAP; } \\
\text { Frontier V } \\
4.1\end{array}$ & & & Panel (D) & - & $\begin{array}{l}\text { Cost adjustment due to } \\
\text { consolidation process }(\mathrm{P})\end{array}$ & Yes & & \\
\hline Portugal & $\begin{array}{l}\text { Yes, using } \\
\text { professional } \\
\text { experts with } \\
\text { economic } \\
\text { degrees. } \\
\end{array}$ & & $\begin{array}{l}\text { Frontier V } \\
4.1 \text {; TSP }\end{array}$ & Tests (D) & & Panel (D) & NA & $\begin{array}{l}\text { Due to data inconsistency } \\
\text { had to exclude one year from } \\
\text { the data }(\mathrm{P})\end{array}$ & Yes; z variables in SFA & & $20 \%$; 3 years $(E-D)$ \\
\hline Slovenia & $\begin{array}{l}\text { With external } \\
\text { support tools } \\
\text { were } \\
\text { developed; } \\
\text { analysis } \\
\text { performed } \\
\text { internally } \\
\end{array}$ & $\begin{array}{l}\text { Economics (A, } \\
\text { OP, L, I) }\end{array}$ & $\begin{array}{l}\text { Frontier V } \\
4.1 \text {; DEA }\end{array}$ & CIA (D) & NA & Int'l (D) & NA & $\begin{array}{l}\text { Unclear and different } \\
\text { structure of OPEX, for } \\
\text { example in some costs for } \\
\text { network losses are included } \\
\text { in operational costs, in others } \\
\text { not (I) }\end{array}$ & Yes; second stage DEA & NA & $10 \%$; 3 years $(\mathrm{E}-\mathrm{D})$ \\
\hline \multicolumn{12}{|c|}{ Rest of Europe } \\
\hline Iceland & $\begin{array}{l}\text { No - } \\
\text { consultant } \\
\text { hired }\end{array}$ & Economics (I) & & Not decided (T\&D) & & Int'l (T\&D) & & Comparability issues & No & $\begin{array}{l}\text { Not decided (E; } \\
\text { T\&D) }\end{array}$ & Not decided \\
\hline Norway & $\begin{array}{l}\text { Mostly } \\
\text { external for } \\
\text { electricity } \\
\text { transmission; } \\
\text { mixture for } \\
\text { distribution }\end{array}$ & $\begin{array}{l}\text { Economics (A, } \\
\text { OP); } \\
\text { Engineering } \\
(\mathrm{OP})\end{array}$ & $\begin{array}{l}\text { LIMDEP; } \\
\text { EMS; } \\
\text { Frontier V } \\
4.1\end{array}$ & $\begin{array}{l}\text { CIA but only in } \\
\text { developing model; } \\
\text { uncertainty taken into } \\
\text { account when } \\
\text { applying results - } \\
40 \% \text { of revenue cap } \\
\text { decided by a } \\
\text { company's own } \\
\text { historical costs } \\
\end{array}$ & & $\begin{array}{l}\text { Int’l (T); } \\
\text { Panel (D) }\end{array}$ & & $\begin{array}{l}\text { Conducted externally, not } \\
\text { aware of any problems (I); } \\
\text { Cost data used for three } \\
\text { recent years, 2004-2006 and } \\
\text { we have not had problems } \\
\text { (P) }\end{array}$ & $\begin{array}{l}\text { Yes; as variables } \\
\text { directly in DEA }\end{array}$ & & $60 \% ; 1$ year $(E-D)$ \\
\hline \multicolumn{12}{|c|}{ Latin America } \\
\hline Argentina & & $\begin{array}{l}\text { Economics and } \\
\text { Engineering }\end{array}$ & & & & $\begin{array}{l}\text { Int'l and } \\
\text { Panel (T) }\end{array}$ & & $\begin{array}{l}\text { Comparison issues (I); lack } \\
\text { of data (P) }\end{array}$ & No & $\begin{array}{l}\text { Score and } \\
\text { subjective }\end{array}$ & \\
\hline
\end{tabular}




\begin{tabular}{|c|c|c|c|c|c|c|c|c|c|c|c|}
\hline & & $\begin{array}{l}(\mathrm{OP}, \mathrm{I}) ; \mathrm{Law} \\
(\mathrm{OP}, \mathrm{L})\end{array}$ & & & & & & & & judgement $(\mathrm{E} ; \mathrm{T})$ & \\
\hline Bolivia & Yes & & & & & & & & & & \\
\hline Brazil & Yes & & EMS & & & $\begin{array}{l}\text { Panel } \\
\text { (T\&D) }\end{array}$ & & NA & No & $\begin{array}{l}\text { Normalisation (E; } \\
\text { T) }\end{array}$ & $\begin{array}{l}10 \% ; 4 \text { years }(E-D) \\
20 \% ; 0 \text { years }(E-T)\end{array}$ \\
\hline Chile & $\begin{array}{l}\text { Cost studies } \\
\text { competitively } \\
\text { tendered; } \\
\text { internal staff } \\
\text { support } \\
\text { selected } \\
\text { consultants. } \\
\end{array}$ & $\begin{array}{l}\text { Economics and } \\
\text { Engineering } \\
\text { (A, OP, L, I) }\end{array}$ & & & & $\begin{array}{l}\text { Previous } \\
\text { results from } \\
\text { consultant } \\
\text { studies } \\
\text { (T\&D) }\end{array}$ & $\begin{array}{l}\text { Previous } \\
\text { results } \\
\text { from } \\
\text { consultan } \\
\text { t studies } \\
\text { (D) }\end{array}$ & NA & No & NA & \\
\hline Colombia & $\begin{array}{l}\text { Yes (D); No } \\
\text { (T) }\end{array}$ & $\begin{array}{l}\text { Economics (A, } \\
\text { L, I); } \\
\text { Engineering } \\
(\mathrm{A}, \mathrm{L})\end{array}$ & $\begin{array}{l}\text { Frontier } \\
\text { Analyst; } \\
\text { EMS }\end{array}$ & & & $\begin{array}{l}\text { Int'l and } \\
\text { Panel } \\
\text { (T\&D) }\end{array}$ & $\begin{array}{l}\text { Int'l and } \\
\text { national } \\
\text { (T); } \\
\text { Panel (D) }\end{array}$ & $\begin{array}{l}\text { Difficult to validate info to } \\
\text { compare, esp. w/ } \\
\text { heterogeneous data (I); lack } \\
\text { of data for T, inconsistent } \\
\text { info for D (P) }\end{array}$ & No & $\begin{array}{l}\text { Asset lifetime } \\
\text { criteria for each } \\
\text { region (E; D) }\end{array}$ & $20 \% ; 5$ years $(\mathrm{G}-\mathrm{T})$ \\
\hline Ecuador & $\begin{array}{l}\text { Yes; } \\
\text { experience } \\
\text { exchanged } \\
\text { with civil } \\
\text { servants from } \\
\text { other } \\
\text { regulatory } \\
\text { bodies. } \\
\end{array}$ & $\begin{array}{l}\text { Economics and } \\
\text { Engineering } \\
\text { (A, I) }\end{array}$ & $\begin{array}{l}\text { Methodolog } \\
\text { ies defined } \\
\text { standard } \\
\text { units of } \\
\text { property } \\
\text { and cost }\end{array}$ & & & Int'l (T\&D) & & $\begin{array}{l}\text { How to apply international } \\
\text { data to local reality }\end{array}$ & No & NA & $50 \%$; 1 year $(E-T \& D)$ \\
\hline Mexico & Yes & $\begin{array}{l}\text { Economics and } \\
\text { Engineering (I) }\end{array}$ & DEAP & & & Int'l (T\&D) & $\begin{array}{l}\text { Panel } \\
\text { (T\&D) }\end{array}$ & $\begin{array}{l}\text { Comparison issues (I); lack } \\
\text { of data (I\&P) }\end{array}$ & No & $\begin{array}{l}\text { Highest scores (E } \\
\text { and G; T\&D) }\end{array}$ & $\begin{array}{l}50 \% ; 5 \text { years }(E-D) \\
10 \% ; 5 \text { years }(E-T) \\
20 \% ; 5 \text { years }(G-T \& D)\end{array}$ \\
\hline Peru & $\begin{array}{l}\text { Internal and } \\
\text { external } \\
\text { consultants }\end{array}$ & $\begin{array}{l}\text { Economics and } \\
\text { Engineering } \\
\text { (A, OP, I); }\end{array}$ & & & & Int'l (T\&D) & - & Sources and lags (I) & & $\begin{array}{l}\text { Simulation of } \\
\text { most efficiency } \\
\text { company }\end{array}$ & \\
\hline Venezuela & & & & $\begin{array}{l}\text { Adjustment (T\&D) - } \\
\text { based on quality of } \\
\text { service and market } \\
\text { composition }(D)\end{array}$ & & & & & & & \\
\hline \multicolumn{12}{|l|}{ Australasia } \\
\hline $\begin{array}{l}\text { New } \\
\text { Zealand }\end{array}$ & $\begin{array}{l}\text { No, external } \\
\text { consultant }\end{array}$ & $\begin{array}{l}\text { Economics (A, } \\
\text { OP); Other - } \\
\text { Productivity (I) }\end{array}$ & & Tests (D) & NA & Panel (D) & NA & $\begin{array}{l}\text { Not really comparable (I); } \\
\text { lack of historic data (P) }\end{array}$ & $\begin{array}{l}\text { Yes; as part of multiple } \\
\text { output variables used in } \\
\text { productivity analysis }\end{array}$ & NA & NA \\
\hline $\begin{array}{l}\text { Northern } \\
\text { Territory }\end{array}$ & & $\begin{array}{l}\text { Economics (A, } \\
\text { L) }\end{array}$ & & & & Panel (D) & - & $\begin{array}{l}\text { Lack of data, different } \\
\text { timeframes }(\mathrm{P})\end{array}$ & $\begin{array}{l}\text { Yes; part of } X \text {-factor } \\
\text { specific to environment } \\
\text { of regulated entity }\end{array}$ & NA & $100 \% ; 10$ years $(E-D)$ \\
\hline Tasmania & $\begin{array}{l}\text { Consultant } \\
\text { engaged to } \\
\text { examine past } \\
+ \text { proposed } \\
\text { expenditures } \\
\end{array}$ & $\begin{array}{l}\text { Economics and } \\
\text { Engineering } \\
\text { (I); }\end{array}$ & & & & $\begin{array}{l}\text { Interstate } \\
\text { comparison } \\
\text { s (D) }\end{array}$ & - & NA & $\begin{array}{l}\text { Yes; taken into account } \\
\text { by consultants in } \\
\text { making judgements }\end{array}$ & NA & \\
\hline
\end{tabular}


A total of 6 regulators carried out their benchmarking analysis exclusively inside their agencies: 2 relatively small European countries (Belgium and Portugal); and 4 Latin American countries (Bolivia, Brazil, Ecuador and Mexico) of mixed sector/country sizes. The Belgian regulator explains that time constraints of less than 2 months for the reviews precluded any engagement of external consultants.

Table 5: Consultant specialism (Question 11)

\begin{tabular}{|l|r|}
\hline Specialism & $\begin{array}{l}\text { Regulators } \\
\text { (Total = 22) }\end{array}$ \\
\hline Economics & 21 \\
\hline Engineering & 15 \\
\hline Law & 4 \\
\hline Other & 4 \\
\hline
\end{tabular}

\subsubsection{In-house software}

As for the types of software programmes used in-house (Question 12), 4 countries indicated use of commercial packages (Finland, Austria, Norway and Colombia), although Finland, Norway and Colombia all use a second package that is non-commercial. A further 8 regulators used one of the non-commercial packages listed (DEAP, EMS, Frontier V4.1, FEAR/R); and there were 3 specific mentions of the use of Microsoft Excel software, which is widely available. All in all, there is a tendency in our sample to favour freely or widely available software which is positive from a transparency perspective.

\subsubsection{Details of adjustments made}

Looking at the details of the efficiency analysis undertaken, firstly we ask at if and how regulators have dealt with uncertainty (Questions 13 and 14). Sixteen of the regulators who use at least one advanced benchmarking technique (DEA, COLS, SFA or process/activity) responded to this question; 6 of those 16 do not use any of the listed methods to adjust for uncertainty. These 6 countries use a mixture of DEA, COLS and process/activity benchmarking. Both of the countries that use SFA (Finland and Portugal) incorporate tests for well-behaved functional form into their analyses.

\subsubsection{Use of international and panel data}

The use of international and panel data is relatively widespread across the surveyed regulators for the electricity industry but not quite as widespread for gas. The use of international data is particularly prevalent in the analysis of electricity transmission companies, where 13 of the 23 regulators who responded to Question 15 used more than 1 year of international data in their price reviews. Eight of the 23 used panel data for transmission companies; and 5 used both international and panel data (Austria, Belgium, Colombia, Hungary and the Netherlands). For electricity distribution, 11 regulators used panel data; 9 used international data; and only 3 (Austria, Colombia and Hungary) used both.

If we look at the gas industry, again a greater number of regulators have used international data in assessing the efficiency of transmission companies ( 5 out of 16 total respondents compared to only 2 for gas distribution). Panel data have been used by 5 regulators for gas distribution and 4 for gas 
transmission. Only 2 regulators use both international and panel data for gas distribution companies (Austria and Ireland); and 3 for gas transmission companies (Austria, Belgium and Ireland).

In both the electricity and gas industries, there are therefore very few countries that use both international and panel data for price reviews. The countries that use both types of data for electricity and gas distribution vary in terms of the number of companies from small (Hungary with 6 electricity distribution companies; Ireland with one gas distribution company) to large (Austria and Colombia, both with over 20 companies in electricity and gas distribution). In fact 14 regulators, with a mixture of small and large sectors, indicated that they have experienced problems in using either international or panel data for benchmarking and 8 of those 14 indicated problems with both. Comparability is the main area of concern in using international data -11 out of 13 regulators referred to this in their responses. Other issues include legal restrictions, difficulties in validating heterogeneous data, and an overall lack of data. Problems with panel data are identified by 11 regulators in total. The most common issues are a lack of data and having incomplete or inconsistent data across companies. ${ }^{11}$

\subsubsection{Incorporation of environmental data}

Incorporating environmental factors (such as weather or age of assets) into the efficiency analysis of regulated companies is another indicator of best practice. Two thirds of the respondents to this question (22 in all) already incorporate environmental factors into their assessments (see Figure 4).

Figure 4: Incorporating environmental factors

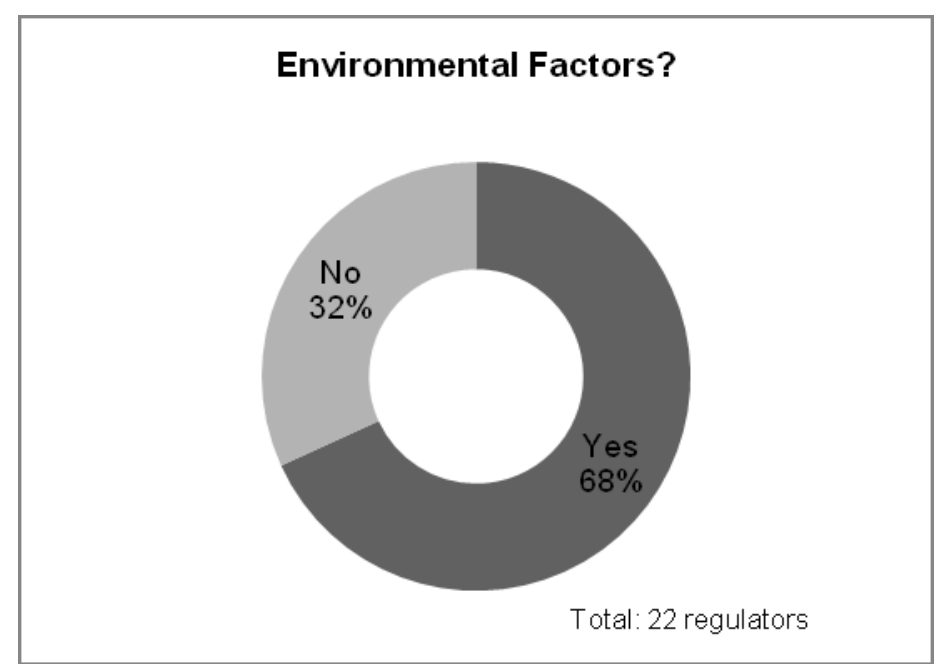

\footnotetext{
${ }^{11}$ Other potential reasons for limited use that are not covered within our survey may lie within the structures of the regulatory agency. In the UK water industry, for example, it has been shown that the UK water regulator does not use panel data even though it is readily available (Weeks and Lay, 2006). Management shortcomings within the regulatory agency have been suggested as the main reason for this outcome.
} 
If we look more closely at the 15 regulators who already incorporate environmental factors in some way, we can see that there is considerable variety in the methods used across countries and regions. Figure 5 gives a breakdown of these responses.

Figure 5: Techniques for incorporating environmental factors

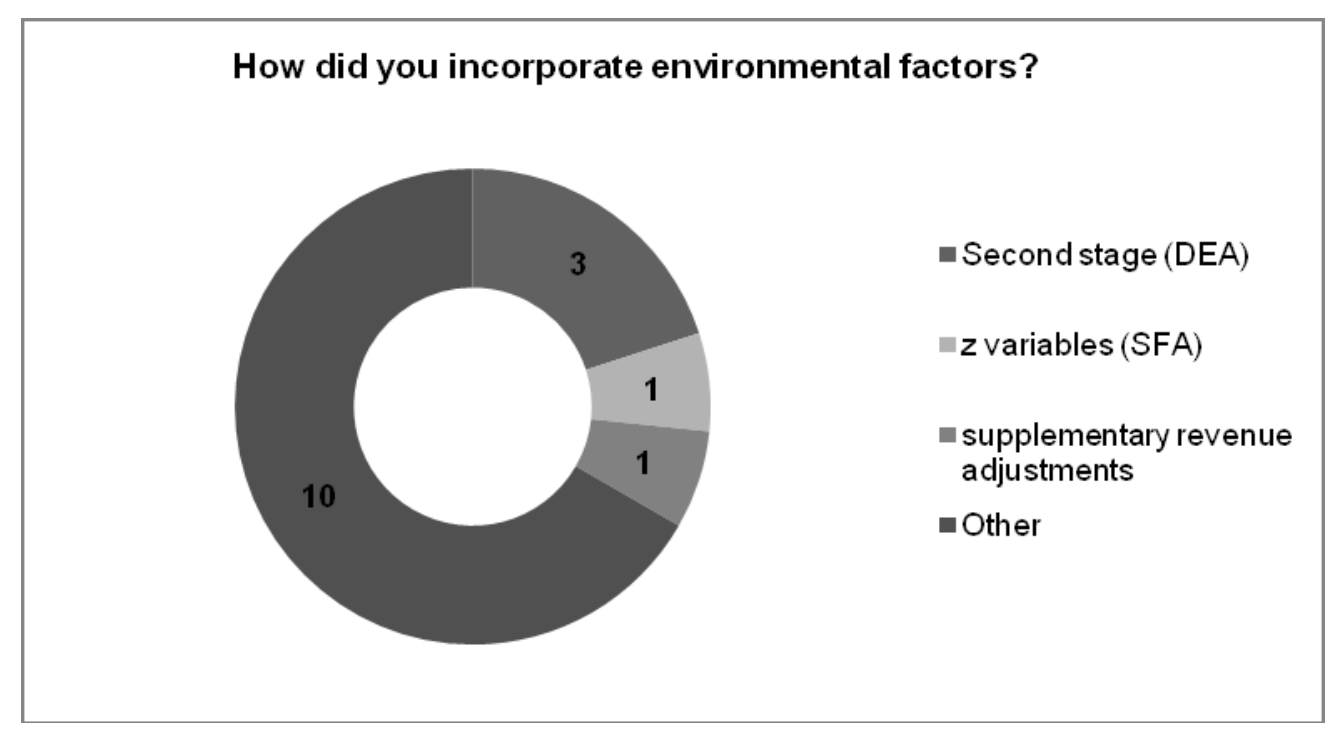

As we can see from the chart, the majority of regulators use methods other than those listed; 9 of the 10 regulators expand on these other methods as follows:

1. Austria: model network analysis (MNA)

2. Belgium: additional outputs in DEA - restrict number of companies on the frontier

3. Finland: percentage of underground cables (proxy for areas); interruption time (proxy for difficulty)

4. Great Britain: as part of composite variable in COLS

5. Netherlands: identification of country specific cost allowances

6. New Zealand: as part of the multiple output variables used in productivity analysis

7. Northern Territory: part of X-factor specific to environment of regulated entity

8. Norway: as variables directly in DEA

9. Tasmania: taken into account by consultants in making their professional judgements

\subsubsection{Selection between results}


Of the 10 regulators that responded to Question 19 on the selection of efficiency where more than one benchmarking technique was used, 4 identified judgement as part of their final decision-making process. The remaining regulators used a variety of methods including averages of efficiency scores, and selection of the highest efficiency score. It appears that improvements could be made to ensure that best practice is more widespread. Although the exact definition of best practice in this area is unclear, we consider that the judgement of the individual regulator should be applied to the final selection process.

1. In terms of the actual reduction in inefficiency Figure 6 plots the average percentage reductions against the number of years over which the measured inefficiency is expected to be reduced for electricity distribution only (Question 20). We have also included the benchmarking techniques mentioned as part of the formal analysis process next to each regulator. ${ }^{12}$ It is difficult to identify a specific pattern of variation by technique. What we can say, however, is that the lower percentage reductions correspond for the most part to regulators that use only one technique in their analysis process. The higher percentage reductions ( $25 \%$ and above) correspond to those that use several techniques (and mainly a combination of COLS and DEA) as well as alternative methods of computing efficiency factors. ${ }^{13}$

Table 6 summarises the responses to the same question for electricity transmission and gas distribution and transmission.

Figure 6: Inefficiency reduction in Electricity Distribution

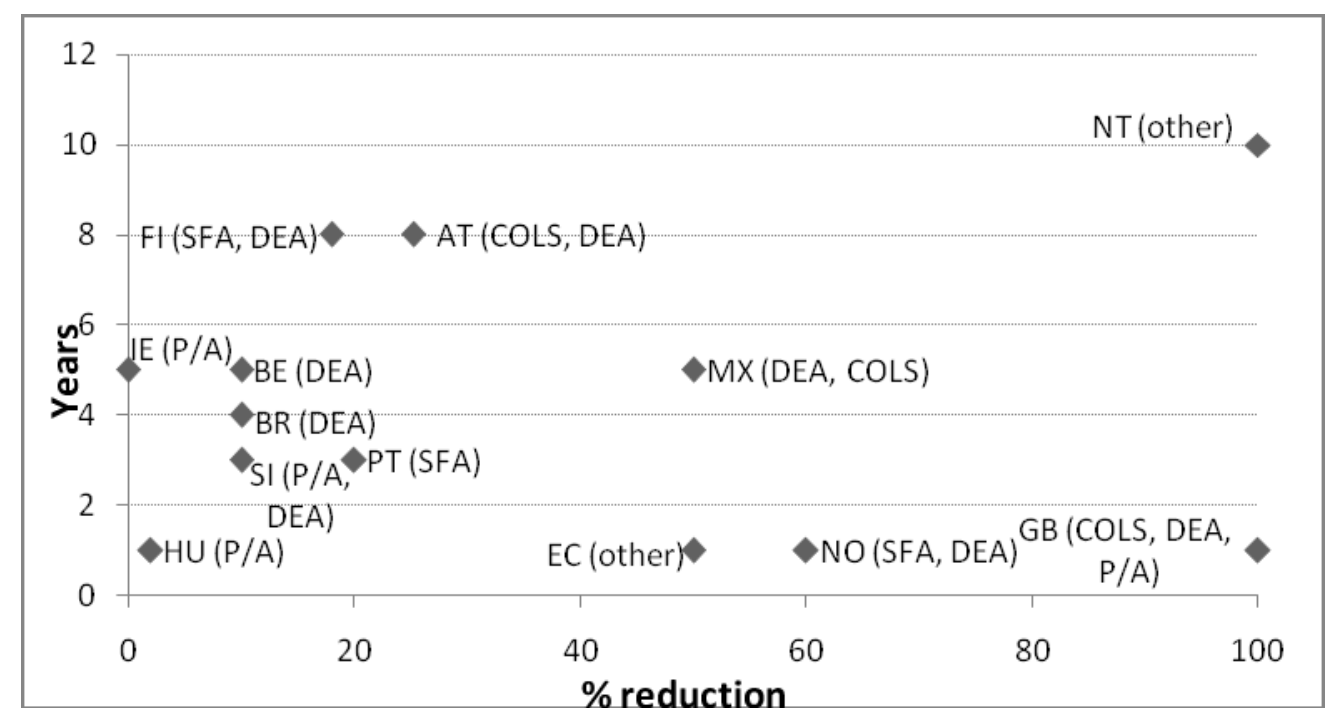

\footnotetext{
${ }^{12}$ The only exception to this is the case of Mexico where DEA and COLS are mentioned as part of the informal analysis but no specific techniques are mentioned as being used formally.

${ }^{13}$ The Northern Territory in Australia bases its X-factor on experience in other Australian jurisdictions; and in Ecuador, percentage caps are used.
} 
Key: AT - Austria; BE - Belgium; BR - Brazil; EC - Ecuador; FI - Finland; GB - Great Britain; HU - Hungary; IE Ireland; MX - Mexico; NO - Norway; NT - Northern Territory; PT - Portugal; SI - Slovenia

Notes:

2. The Irish response states that the period of reduction is expected to be 1 to 5 years; the maximum of 5 years is reflected in the figure;

3. The British response states that the inefficiency reduction is to be reached by the beginning of the new period, i.e. in the first year of the new price review period.

Table 6: Inefficiency reduction and period (Q. 20)

\begin{tabular}{lrrrrrr}
\hline Country & $\mathbf{E}(\mathbf{T})$ \% & $\mathbf{E}(\mathbf{T})$ years & $\mathbf{G}(\mathbf{D}) \%$ & $\mathbf{G}(\mathbf{D})$ years & $\mathbf{G}(\mathbf{T}) \%$ & $\mathbf{G}(\mathbf{T})$ years \\
\hline Austria & 25.24 & 8 & 25.94 & 10 & 25.94 & 10 \\
Belgium & - & - & 8 & 5 & - & - \\
Brazil & 20 & 0 & - & - & - & - \\
Colombia & - & & - & - & 20 & 5 \\
Ecuador & 50 & 1 & - & - & - & - \\
& & - & & beginning of & - & - \\
Great Britain & - & - & 100 & new period & - & 1 \\
Hungary & 2 & 1 & 2 & 1 & 2 & 5 \\
Ireland & 0 & 1 to 5 & 2.5 & 5 & 2 & 5 \\
Mexico & 10 & 5 & 20 & 5 & 20 & - \\
Netherlands & 20 & 3 & - & - & - & \\
\hline
\end{tabular}

\subsubsection{Practicality and desirability of applying latest advances}

Our final question aims to give regulators the opportunity to comment on the practicality and desirability of using the latest advances in benchmarking techniques. Interestingly, all responses to this question came from countries that use some form of benchmarking in either the electricity or gas industry. Very few countries gave unconditionally positive responses to this question. Portugal's and Mexico's responses are among the most positive in that they do not mention any limitations of the techniques. The Portuguese regulator instead focuses on the overarching goal of using advanced benchmarking techniques for the regulation of electricity and gas distribution and transmission companies: consumer protection. The Mexican regulator considers advanced techniques to be very important across the board, although at present advanced techniques are not in use for the electricity industry.

Likewise, very few countries gave unconditionally negative responses to the same question. The Peruvian regulator is alone in indicating that advanced techniques are not desirable or practical in the case of electricity transmission, and in the case of both gas distribution and transmission. The remaining countries on the whole indicate support for advanced techniques but point to a number of limitations, particularly concerning data availability, comparability with other countries and difficulties in interpreting results. 
Finally, returning briefly to the subject of human resource constraints, we can see some evidence from the responses to the second half of our survey that lower income countries may experience difficulties or delays in applying the latest advances. Of the 17 lower-middle and upper-middle income countries, 7 use advanced techniques and 3 use alternative benchmarking methods in electricity regulation; however only one country adjusts for uncertainty (Venezuela); one incorporates environmental factors (Poland); and one uses a mixture of internal and external analysis (Peru). Again looking at electricity regulation, 13 of the 25 high-income countries/regions use advanced techniques and 2 use alternative methods; 8 adjust for uncertainty, 13 incorporate environmental factors and 8 use a combination of internal and external analysis. It appears that the rate of adoption of the latest advances is faster in higher-income countries, where human resource constraints are not as serious a concern as in lower-income countries.

\section{Best practice index}

As we have seen from a close look at the responses to our survey, there are considerable differences in the types of techniques used and their methods of application across countries. In order to simplify our cross-country comparison, we construct a best practice index for each industry based on Lovell's identification of best practice indicators for efficiency analysis (2006). The idea here is to assign scores to each country based on their levels of sophistication in the use of efficiency analysis. We are mainly looking for indications of the use of best practice in the incentive regulatory process and have computed an industry score for each jurisdiction that is an average of best practice in distribution and transmission. ${ }^{14}$ The separate index scores for distribution and transmission by industry can be found in the Appendix.

The aim of this exercise is to distil the detailed information from Tables 2 and 4 into a format that allows us to draw some conclusions on the overall state of the application of advances in benchmarking methods. We do not attempt to draw conclusions on the individual countries and recognise that to do so would require a much more sophisticated analysis of the individual processes and contexts. Again, we emphasise that our index is based on survey responses; the details of which have been given in the previous section. We have chosen a pragmatic analytic approach given the data available to us and our stated aims.

Best practice can be a problematic concept, particularly when making comparisons across countries with very different regulatory, economic and political contexts. It is still a useful concept, however, in terms of defining a benchmark from which deviations can be explained. It may in fact be optimal for a country to implement some but not all best practice methods due to country-specific constraints (human resource, budgetary, data and institutional). Rodrik's work on second-best institutions is instructive here (2008), i.e. the methods in place may be more appropriate given country context. Our work provides a starting point for a discussion of these issues; further work would be useful in exploring the determinants of best practice and associated deviations.

\footnotetext{
${ }^{14}$ For jurisdictions where there are no transmission companies, the score reflects performance in distribution only.
} 


\subsection{Index construction}

Table 7 summarises the indicators used to construct the index and identifies the relevant survey questions used to compute the scores. Each of the indicators has equal weighting in the index; and for all indicators the maximum score is 1 . In most cases, the indicators are binary, i.e. 1 for a positive response and 0 for a negative response. In the case of two of the indicators (numbers 1 and 8 ) we have differentiated levels of sophistication further in order to incorporate a greater level of detail.

Table 7: Best practice index

\begin{tabular}{|c|c|c|c|}
\hline Score & ID & Indicator & $\begin{array}{l}\text { Corresponding } \\
\text { survey questions }\end{array}$ \\
\hline $1,0.5,0$ & 1 & $\begin{array}{l}\text { Current use of DEA, COLS, SFA and/or process/activity } \\
\text { benchmarking; } 0.5 \text { for concrete plans to use one or more } \\
\text { of these techniques }\end{array}$ & Q. 3 \\
\hline 1,0 & 2 & $\begin{array}{l}\text { Use of more than one of above benchmarking techniques } \\
\text { in most recent price review }\end{array}$ & Q. 3 and 5 \\
\hline 1,0 & 3 & Totex modelling & Q. 6 \\
\hline 1,0 & 4 & Use of panel data & Q. 15 \\
\hline 1,0 & 5 & $\begin{array}{l}\text { Dealing with uncertainty: Full score for DEA, SFA, COLS or } \\
\text { Process/Activity if tests for well-behaved functional form, } \\
\mathrm{CIA} \text { or specific adjustment }\end{array}$ & Q. 13 \\
\hline 1,0 & 6 & Incorporation of environmental factors & Q. 17 \\
\hline 1 & 7 & $\begin{array}{l}\text { Use any benchmarking techniques and have either } \geq 30 \\
\text { companies or }<30 \text { companies and use of international } \\
\text { data (Large dataset) }\end{array}$ & Q. 1 and 15 \\
\hline $1,0.5,0$ & 8 & $\begin{array}{l}\text { Mixture of both external and internal analysis }=1 ; \\
\text { Sophisticated internal analysis (i.e. using one of advanced } \\
\text { benchmarking techniques) }=0.5 ; \text { External analysis only }=0\end{array}$ & Q. 11 \\
\hline $\begin{array}{l}\text { Max. } \\
\text { score: } 8\end{array}$ & & & \\
\hline
\end{tabular}

For the first indicator, 0.5 is given to countries that have definite plans to use advanced benchmarking techniques. This is not awarded to countries that mention the possibility of considering benchmarking in the future. Instead, we are looking here for commitment to adoption, i.e. countries that may already be 
in the preparatory or advanced stages of changing regulatory procedures. ${ }^{15}$ The fifth indicator measures the sophistication of dealing with uncertainty. As there are different methods of dealing with uncertainty depending on the benchmarking technique adopted, we award the full score to any regulator that has made a specific adjustment for uncertainty, has used confidence interval analysis (CIA) or tests for well-behaved functional form, i.e. has made an attempt to test or adjust the scores to ensure more defensible implementation of the results.

A large dataset is desirable in efficiency analysis. We include a measure of this in our index by awarding a full point to those countries or regions that have either 30 or more companies, or less than 30 companies and use international data. This is admittedly an imperfect measure of the size of datasets ultimately used; however it gives us a strong indication of the regulatory commitment of countries and regions with smaller sector sizes to increase the quality of their data. For the last indicator, we measure the involvement of individual regulators in the analysis process as well as the propensity of regulators to improve their process by contracting outside assistance. We award the full score to those that use a mixture of both internal and external analyses on the basis that this allows for the greatest amount of involvement without sacrificing specialism and sophistication. For those that use a sophisticated method of internal analysis, we award a half point; and for those that rely solely on external analysis we award zero.

\subsection{Index scores}

We have computed separate best practice index scores for each industry. Table 8 and Table 9 summarise the results. Scores are reported from highest to lowest for each industry. The scores are averages of best practice scores for transmission and distribution, i.e. the maximum score is 8 and to perform close to this, elements of best practice must be found in the regulation of both transmission and distribution companies. The scores are based solely on the responses to our survey as detailed in Section 4. Table A.1 in the Appendix illustrates how scores can differ considerably between transmission and distribution. For example, Great Britain scores 4.5 overall in both combined indices; scoring 6 for distribution and 3 for transmission. Argentina's score of 2 in the combined electricity index reflects application of best practice methods in transmission only where the best practice score is 4; benchmarking methods are not used in the regulation of distribution companies.

For both electricity and gas, there are a select few countries leading the way in the application of best practice efficiency analysis techniques. The vast majority of regulators are clustered at the bottom of the score tables and this is even more pronounced in the gas industry where well over half of the regulators receive a score of two or less. There is greater variety of scores in the electricity industry. We also see some regional convergence at the top of the electricity score table - five of the six with scores of 5 and

\footnotetext{
${ }^{15}$ Germany and Iceland have both been awarded 0.5 for their plans at the time the survey was taken to improve the benchmarking methodology used as part of their regulatory processes. These methods have now been applied and if the survey was undertaken again later this year, the scores for both countries would be radically different.
} 
above are EU member states. Generally speaking however, best practice is far from widespread and this is particularly the case in gas network regulation.

Table 8: Electricity best practice index scores (Max $=8$ )

\begin{tabular}{|l|r|}
\hline Country & $\begin{array}{c}\text { Electricity } \\
\text { Index score }\end{array}$ \\
\hline Austria & 7 \\
\hline Finland & 6 \\
\hline Belgium & 5.5 \\
\hline Hungary; Ireland; Norway & 5 \\
\hline Great Britain & 4.5 \\
\hline Colombia & 3.25 \\
\hline Netherlands; Slovenia & 3 \\
\hline Estonia & 2.5 \\
\hline Portugal; Brazil & 2.25 \\
\hline Argentina; Chile; Denmark; New Zealand; Northern & 2 \\
\hline Territory; Tasmania; Venezuela & 1.5 \\
\hline Bolivia; Peru & 1 \\
\hline Panama; Poland; Ecuador & 0.5 \\
\hline Germany; Iceland & 0 \\
\hline Croatia; Cyprus; Czech Republic; Dominican Republic; & \\
\hline El Salvador; Greece; Lithuania; Luxembourg; Mexico; & \\
\hline Nicaragua; Romania; South Australia; Sweden; & \\
\hline Uruguay; Western Australia &
\end{tabular}

Table 9: Gas best practice index scores

\begin{tabular}{|l|r|}
\hline Country & Gas Index score \\
\hline Austria & 7 \\
\hline Mexico & 5.5 \\
\hline Belgium & 5 \\
\hline Great Britain & 4.5 \\
\hline Colombia & 2.75 \\
\hline Denmark; Estonia; Hungary; Ireland & 2 \\
\hline
\end{tabular}




\section{Conclusions}

It is clear from the results of our survey that only a small number of regulators do not use or are not actively considering the use of advanced benchmarking techniques in analyzing the efficiency of gas and electricity network companies. It is also clear, however, that there is a wide variety in the practices that have been adopted internationally. We expected to find some clear consensus on the techniques favoured by regulated industry. Instead we found that in the gas industry it appears to be too early to say. In the electricity industry we can certainly see a clearer trend towards the use of process/activity and DEA in both transmission and distribution over other advanced benchmarking techniques; however alternatives to best practice techniques are prevalent, particularly in electricity distribution.

The strongest evidence of convergence is within the EU where very few countries do not use and are not planning to use benchmarking techniques, however sophisticated. Other regions also show some evidence of regulators being influenced by their neighbours but not always in a positive way, i.e. some regulators in Latin American and Australia ${ }^{16}$ mention the lack of regional data and experience with sophisticated benchmarking techniques as obstacles to adoption. While there is some evidence of large country effects in implementing more sophisticated benchmarking, there are also several examples of small countries carrying out sophisticated analyses. This is particularly the case for electricity regulation and is made possible in part by the availability of international data.

In terms of the details of the benchmarking analysis process, there are a number of positive signs, including the widespread use of economics (combined with engineering); the use of a mixture of internal and external expertise in the majority of regulatory agencies; and the relatively widespread use of international and panel data in electricity regulation. Despite these encouraging signs, there are very few regulators that adhere closely to Lovell's principles of what constitutes best practice.

A number of developments would help to ensure that best practice continues to become more widespread and that countries keep up with new techniques as they emerge. Most of our survey respondents pointed to a number of limitations of advanced benchmarking techniques, particularly in terms of data requirements, comparability and interpretation difficulties. Advancing cooperation between regulators in different countries and regions has the potential to overcome some of these

\footnotetext{
${ }^{16}$ Australia has recently moved towards national regulation of electricity and gas distribution (via the Australian Energy Regulator), ending state regulation of these utilities by 2010.
} 
obstacles and this is particularly the case where international data is concerned. One of the most often cited problems with using international data is the difficulty of comparing and applying data to different country contexts. Further efforts to standardise data within and across countries are essential in order to alleviate this problem.

Making sure that increasing complexity doesn't lead to the costs of efficiency analysis outweighing the benefits can be particularly important in developing countries where human resource constraints are a significant challenge in regulatory agencies. Demonstrating that more sophisticated benchmarking methods can add value to the price setting process is an important part of firmly establishing the desirability and practicality of using the latest advances. Furthermore, improving the free (or the addons in Microsoft Excel) software packages that are available for efficiency analysis would go a long way towards contributing to transparency and progress in making best practice techniques more widespread. 


\section{References}

Agrell, P. and P. Bogetoft (2004). Evolutionary Regulation: From CPI-X towards contestability. Position paper for Economics Network for Competition and Regulation.

Charnes, A., W. W. Cooper and E. Rhodes (1978). Measuring the efficiency of decision making units. European Journal of Operational Research 2(6): 429-444.

Coelli, T., D. S. P. Rao, C. O'Donnell and G. E. Battese (2005). An Introduction to Efficiency and Productivity Analysis. New York, New York, Springer Science and Business Media Inc.

Cook, W. D. and L. M. Seiford (2009). Data envelopment analysis (DEA) - Thirty years on. European Journal of Operational Research 192(1): 1-17.

De Witte, K. and R. Marques (2007). Designing Incentives in Local Public Utilities: An international Comparison of the Drinking Water Sector EGPA Conference.

Domah, P., M. Pollitt and J. Stern (2002). Modelling the costs of energy regulation: Evidence of human resource constraints in developing countries. Cambridge-MIT Institute. CMI Working Paper 11; Department of Applied Economics Working Paper 0229.

Farrell, M. J. (1957). The Measurement of Productive Efficiency. Journal of the Royal Statistical Society. Series A (General) 120(3): 253-290.

Farsi, M., A. Fetz and M. Fillipini (2007). Benchmarking and regulation in the electricity distribution sector. Centre for Energy Policy and Economics, CEPE Working Paper 54.

Giannakis, D., T. Jamasb and M. Pollitt (2005). Benchmarking and incentive regulation of quality of service: an application to the UK electricity distribution networks. Energy Policy 33(17): 22562271.

Hawdon, D. (2003). Efficiency, performance and regulation of the international gas industry--a bootstrap DEA approach. Energy Policy 31(11): 1167-1178.

Jamasb, T. and M. Pollitt (2001). Benchmarking and regulation: international electricity experience. Utilities Policy 9(3): 107-130.

Jamasb, T. and M. Pollitt (2003). International benchmarking and regulation: an application to European electricity distribution utilities. Energy Policy 31(15): 1609-1622.

Jamasb, T. and M. Pollitt (2007). Incentive regulation of electricity distribution networks: Lessons of experience from Britain. Energy Policy 35(12): 6163-6187.

Joskow, P. L. (2006). Incentive Regulation in Theory and Practice: Electricity Distribution and Transmission Networks. Electricity Policy Research Group. EPRG Working Paper 0511/Cambridge Working Paper in Economics 0607.

Littlechild, S. (1983). Regulation of British Telecommunications' Profitability. London: Department of Industry.

Lovell, K. (1993). Production Frontiers and Productive Efficiency. The Measurement of Productive Efficiency. H. O. Fried, K. Lovell and S. S. Schmidt. New York, New York, Oxford University Press: 3-67.

Lovell, K. (2006). Frontier Analysis: Recent Advances and Future Challenges. North American Productivity Workshop, Stern School of Business, New York University, New York.

Pollitt, M. (2008). The future of electricity (and gas) regulation in a low-carbon policy world. Energy Journal 29(Special Issue): 63-94.

Pollitt, M. and J. Stern (2009). Human resource constraints for electricity regulation in developing countries: Has anything changed? Electricity Policy Research Group. EPRG Working Paper 0910/ Cambridge Working Paper in Economics CWPE 0914. 
Rodrik, D. (2008). Second-best institutions. American Economic Review 98(2): 100-104.

Weeks, M. and H. Lay (2006). Efficiency Measurement in the Privatised English and Welsh Water and Sewerage Industry 1992-2004. 13th International Conference on Panel Data, Cambridge, UK.

$\mathrm{Yu}, \mathrm{W} ., \mathrm{T}$. Jamasb and M. Pollitt (2009). Does weather explain the cost and quality performance? An analysis of UK electricity distribution companies. Energy Policy (forthcoming). 


\section{Appendix}

Table A.1: Best practice scores separated for Distribution and Transmission

\begin{tabular}{|c|c|c|c|c|}
\hline $\begin{array}{l}\text { E- Electricity } \\
\text { G- Gas } \\
\text { D- Distribution } \\
\text { T- Transmission }\end{array}$ & $E(D)$ & $E(T)$ & G (D) & $G(T)$ \\
\hline Argentina & 0 & 4 & $\mathrm{n} / \mathrm{a}$ & $\mathrm{n} / \mathrm{a}$ \\
\hline Austria & 7 & 7 & 7 & 7 \\
\hline Belgium & 4.5 & 6.5 & 4.5 & 5.5 \\
\hline Bolivia & 1.5 & 1.5 & $\mathrm{n} / \mathrm{a}$ & $\mathrm{n} / \mathrm{a}$ \\
\hline Brazil & 1 & 3.5 & $\mathrm{n} / \mathrm{a}$ & $\mathrm{n} / \mathrm{a}$ \\
\hline Chile & 2 & 2 & 1 & na \\
\hline Colombia & 3.5 & 3 & 2 & 3.5 \\
\hline Croatia & 0 & 0 & 0 & 0 \\
\hline Cyprus & 0 & 0 & $\mathrm{n} / \mathrm{a}$ & $\mathrm{n} / \mathrm{a}$ \\
\hline Czech Republic & 0 & 0 & 0 & 0 \\
\hline Denmark & 4 & 0 & 2 & $\mathrm{n} / \mathrm{a}$ \\
\hline \multicolumn{5}{|l|}{ Dominican } \\
\hline Republic & 0 & 0 & $\mathrm{n} / \mathrm{a}$ & $\mathrm{n} / \mathrm{a}$ \\
\hline Ecuador & 1 & 1 & $\mathrm{n} / \mathrm{a}$ & $\mathrm{n} / \mathrm{a}$ \\
\hline El Salvador & 0 & 0 & $\mathrm{n} / \mathrm{a}$ & $\mathrm{n} / \mathrm{a}$ \\
\hline Estonia & 3 & 2 & 2 & 2 \\
\hline Finland & 8 & 4 & 0 & 0 \\
\hline Germany & 0.5 & 0.5 & 0.5 & 0.5 \\
\hline Great Britain & 6 & 3 & 6 & 3 \\
\hline Greece & 0 & 0 & 0 & 0 \\
\hline Hungary & 5 & 5 & 4 & 0 \\
\hline Iceland & 0.5 & 0.5 & $\mathrm{n} / \mathrm{a}$ & $\mathrm{n} / \mathrm{a}$ \\
\hline Ireland & 5 & 5 & 2 & 2 \\
\hline Lithuania & 0 & 0 & 0 & 0 \\
\hline Luxembourg & 0 & 0 & 0 & 0 \\
\hline Mexico & 0 & 0 & 6 & 5 \\
\hline Netherlands & 0 & 6 & 0 & 0 \\
\hline New Zealand & 4 & 0 & 0 & $\mathrm{n} / \mathrm{a}$ \\
\hline Nicaragua & 0 & 0 & $\mathrm{n} / \mathrm{a}$ & $\mathrm{n} / \mathrm{a}$ \\
\hline $\begin{array}{l}\text { Northern } \\
\text { Territory, }\end{array}$ & 2 & $\mathrm{n} / \mathrm{a}$ & $\mathrm{n} / \mathrm{a}$ & $\mathrm{n} / \mathrm{a}$ \\
\hline
\end{tabular}




\begin{tabular}{|lllll|}
\hline Australia & & & & \\
Norway & 7 & 3 & $\mathrm{n} / \mathrm{a}$ & $\mathrm{n} / \mathrm{a}$ \\
Panama & 1 & 1 & $\mathrm{n} / \mathrm{a}$ & $\mathrm{n} / \mathrm{a}$ \\
Peru & 3 & 0 & 0 & 0 \\
Poland & 2 & 0 & 0 & 0 \\
Portugal & 4.5 & 0 & 0 & 0 \\
Romania & 0 & 0 & 0 & 0 \\
Slovenia & 6 & 0 & 0 & 0 \\
South Australia & 0 & 0 & 0 & $\mathrm{n} / \mathrm{a}$ \\
Spain & 0 & 0 & 1 & 1 \\
Sweden & 0 & 0 & 0 & 0 \\
Tasmania, & & & & \\
Australia & 2 & $\mathrm{n} / \mathrm{a}$ & $\mathrm{n} / \mathrm{a}$ & $\mathrm{n} / \mathrm{a}$ \\
Uruguay & 0 & 0 & 0 & 0 \\
Venezuela & 2 & 2 & $\mathrm{n} / \mathrm{a}$ & $\mathrm{n} / \mathrm{a}$ \\
Western & & & & \\
Australia & 0 & 0 & 0 & 0 \\
\hline
\end{tabular}

